\title{
Incorporating the Effect of DEM Resolution and Accuracy for Improved Flood Inundation Mapping
}

Siddharth Saksena ${ }^{1}$ and Venkatesh Merwade $^{2}$

${ }^{1}$ Graduate Research Assistant, Lyles School of Civil Engineering, 550 Stadium Mall Drive,

34 Purdue University, West Lafayette, IN 47907.

${ }^{2}$ Associate Professor, Lyles School of Civil Engineering, 550 Stadium Mall Drive, Purdue University, West Lafayette, IN 47907. Phone: (765) 494-2176, Fax: (765) 494-0395, Email:

38 vmerwade@purdue.edu (corresponding author).

39 


\section{Abstract}

2 Topography plays a major role in determining the accuracy of flood inundation areas. However,

3 many areas in the United States and around the world do not have access to high quality

4 topographic data in the form of Digital Elevation Models (DEM). For such areas, an improved

5 understanding of the effects of DEM properties such as horizontal resolution and vertical

6 accuracy on flood inundation maps may eventually lead to improved flood inundation modeling

7 and mapping. This study attempts to relate the errors arising from DEM properties such as spatial

8 resolution and vertical accuracy to flood inundation maps, and then use this relationship to create

9 improved flood inundation maps from coarser resolution DEMs with low accuracy. The results

10 from the five stream reaches used in this study show that water surface elevations (WSE) along

11 the stream and the flood inundation area have a linear relationship with both DEM resolution and

12 accuracy. This linear relationship is then used to extrapolate the water surface elevations from

13 coarser resolution DEMs to get water surface elevations corresponding to a finer resolution

14 DEM. Application of this approach show that improved results can be obtained from flood

15 modeling by using coarser and less accurate DEMs, including public domain datasets such as the

16 National Elevation Dataset and Shuttle Radar Topography Mission (SRTM) DEMs. The

17 improvement in the WSE and its application to obtain better flood inundation maps is dependent

18 on the study reach characteristics such as land use, valley shape, reach length and width.

19 Application of the approach presented in this study on more reaches may lead to development of

20 guidelines for flood inundation mapping using coarser resolution and less accurate topographic

21 datasets.

22 Keywords: Flood Inundation Maps; Topographic Datasets; DEM Resolution; HEC-RAS; DEM

23 Accuracy 
2 According to the U.S. National Weather Service, floods account for an average of 89 deaths and

3 property losses up to $\$ 8.2$ billion per year in the Unites States. Flood risk areas in the U.S. are

4 usually identified using the flood inundation maps provided by the Federal Emergency

5 Management Agency (FEMA). Even though these maps use the best available technical data to

6 identify flood prone areas, they have varying level of uncertainties (Aycock \& Wang, 2004;

7 Merwade et al., 2008; Wang \& Zheng, 2005). These uncertainties arise from one or more

8 sources, including topography data, discharge measurements, choice of model, model

9 assumptions, and model parameters (Hall et al., 2005; Jung \& Merwade, 2011; Lin et al., 2012;

10 Pappenberger et al., 2005; Pappenberger et al., 2006; Rayburg et al., 2009; Srinivas et al., 2008;

11 Straatsma \& Huthoff, 2011; Werner et al., 2005). Among these various uncertain sources,

12 topography has been reported to be one of the major contributors to the overall accuracy of flood

13 inundation maps (Bates et al., 2003; Brandt, 2005; Cook \& Merwade, 2009; Tate et al., 2002).

14 Generally, topography data in the form of a Digital Elevation Model (DEM) are used in creating

15 a hydraulic or hydrodynamic model, and in mapping the flood inundation extent. With the

16 growing availability of LiDAR (Light Detection and Ranging) data in many states in the U.S.,

17 DEMs derived from LiDAR are increasingly used in the delineation of flood inundation areas.

18 The horizontal resolution and the vertical accuracy associated with LiDAR data are significantly

19 better compared to the old DEMs derived from contour surveys, cartography, photogrammetry,

20 interferometry and radar imaging. For example, a LiDAR derived DEM can have horizontal

21 resolution of as high as $0.5 \mathrm{~m}$, and the reported vertical accuracy is in the range of 0.15 to $0.25 \mathrm{~m}$

22 (Aguilar et al., 2010; Giglierano, 2010; Smith, 2010). On the other hand, the vertical accuracy of 
1 old DEMs can range anywhere from 2 to $22 \mathrm{~m}$ (Gesch, 2007; Li \& Wong, 2010; Rutter et al.,

2 2010). As a result, the flood inundation maps derived from LiDAR are much more accurate

3 compared to the maps derived by using any other available topographic datasets in the world

4 (Casas et al., 2006; Charlton et al., 2003; Schumann et al., 2008).

5 While the flood maps derived by using LiDAR are accurate, collecting LiDAR data is very 6 expensive. In the U.S., LiDAR data are available for less than 40 percent of the continental states

7 (Snyder, 2012). LiDAR data derived from high point density elevation measurements or smaller

8 post-spacing increase the survey costs and computational time considerably due to handling of

9 vast amount of data, higher sensor pulse rates, and lower flight altitudes (Aguilar et al., 2010;

10 Raber et al., 2007). While the U.S. and other developed regions in the world have resources to

11 collect LiDAR data, many regions in the world depend on coarser resolution, less accurate

12 DEMs derived from Shuttle Radar Topography Mission (SRTM) and Interferometric Synthetic

13 Aperture Radar (IfSAR) for creation of flood inundation maps (Sanders, 2007). The question this

14 study is attempting to address is: how can the accuracy of flood inundation maps derived from

15 coarser DEMs be improved in the absence of any better topographic information such as from

16 LiDAR?

17 Two key attributes or properties of a DEM, including the horizontal resolution and the vertical

18 accuracy, are important in flood inundation mapping (Gallant et al., 1997; Haile et al., 2005).

19 Many studies in the past have focused on understanding the importance of DEM resolution in

20 flood inundation mapping and have concluded that higher resolution DEMs produce more

21 accurate flood maps when compared to coarser resolution DEMs which over-predict the flood

22 extents (Brandt, 2005; Cook \& Merwade, 2009; Werner, 2001). Specifically, for the same 
1 vertical accuracy, a coarser resolution DEM will produce higher flood inundation extent. The

2 vertical accuracy of a DEM is affected by its source, sampling techniques and interpolation

3 techniques (Bater \& Coops, 2009; Burrough, 1986; Chaplot et al., 2006; Heritage et al., 2009;

4 Merwade, 2009; Smith et al., 2004). Studies based on comparative analysis of vertical accuracy

5 of DEMs have concluded that LiDAR datasets have the least vertical error when compared to

6 other available DEMs used for hydraulic modeling such as the United States Geological Survey

7 (USGS) National Elevation Dataset (NED 10 and NED 30), Interferometric Synthetic Aperture

8 Radar (IfSAR), Advanced Spaceborne Thermal Emission and Reflection (ASTER), Composite

9 DEM (CODEM) and Shuttle Radar Topography Mission (SRTM) (Gonga-Saholiariliva, 2011;

10 Heritage et al., 2009; Hodgson et al., 2003; Schumann et al., 2008).

11 In order to model and remove DEM errors, many studies have focused on identifying the spatial

12 distribution of vertical errors and developing error distribution surfaces (Hodgson \& Bresnahan,

13 2004; Höhle \& Höhle, 2009; Hu et al., 2009; Stal et al., 2011). Recent error distribution models

14 have focused on dividing the errors into theoretical form, which includes errors due to data

15 capture and empirical form, which includes errors due to information loss (Aguilar et al., 2010).

16 Some models have used geographically weighted regression equations derived from terrain

17 parameters to create a single multivariate model for the entire study area suggesting a localized

18 dependence on terrain parameters (Carlisle, 2005; Erdoğan, 2010). Even though both these

19 models provide a better representation of the spatial distribution of DEM errors, their accuracy is

20 highly dependent on the sample size of the observed data and can produce unrealistic values of

21 elevations for certain regions. As a result, the application of error surfaces created using these

22 models to correct topographic datasets for use in hydraulic modeling is tedious and unreliable

23 (Wise, 2011; Yue et al., 2007). 
1 If DEM errors cannot be removed completely using theoretical or regression models, then

2 techniques to reduce the impact of these errors on flood mapping need to be developed.

3 Similarly, while the effect of DEM resolution and vertical accuracy on flood inundation maps is

4 well studied, an attempt to incorporate this knowledge in improving the quality of flood

5 inundation maps is needed.

6 The overall goal of this paper is to improve the quality of flood inundation maps by rectifying

7 the error induced by the DEM resolution and accuracy. This goal is accomplished by addressing

8 the following specific objectives: (1) develop a relationship between flood inundation area and

9 DEM properties such as horizontal resolution and vertical accuracy; (2) create flood inundation

10 maps from low quality (coarser horizontal resolution and/or low vertical accuracy) DEMs by

11 incorporating the relationship developed in the first objective; and (3) compare the improvement

12 in flood inundation maps developed in (2) with the ones developed using LiDAR for the same

13 areas. These objectives are satisfied by creating multiple topographic datasets through

14 resampling and error analysis, and using these datasets to produce flood inundation maps for six

15 stream reaches in the U.S.

\section{Study Area and Data}

17 Six stream reaches in the U.S., as shown in Figure 1, are used in this study. These reaches are

18 chosen based on varying reach length, slope, geographic and climate settings, impervious cover

19 and land use characteristics to provide a range of attributes to study the effect on hydraulic

20 modeling. Among these six reaches, the Iowa River reach is primarily used for validation of

21 results obtained by using the other five reaches. Strouds Creek is a tributary of Eno River in

22 North Carolina, and it is the smallest reach with an urban floodplain, V-shaped valley and history 
1 of high floods. The meandering Tippecanoe River reach near Winamac, Indiana has a highly

2 developed floodplain with commercial and residential buildings. The St. Joseph River reach near

3 Elkhart, Indiana has urban land use, U-shaped valleys and highly developed floodplain. The city

4 of Elkhart has experienced many flood disasters in the past including some major ones in 1908,

5 1950, 1982 and 1985. The East Fork White River reach near Bedford, Indiana, is a tributary of

6 the Wabash River, and is surrounded by industrial and agricultural areas. The main channel is

7 surrounded by trees and natural vegetation which act as natural levees for restricting flow into

8 the floodplain. The Clear Creek reach in Iowa, which is used for validation, has shallow main

9 channel and flat terrain with cities of Oxford and Coralville situated within its floodplain. The

10 Brazos River reach in Texas is the largest reach with a shallow main channel and meandering

11 bends. The study area around this reach has recorded major floods in the past which led to the 12 provision of levees around the main channel.

13 Hydraulic modeling for all study reaches is performed by using 100 -year return period flow. A

14 high flow value is chosen because the floodplains for the large study reaches do not get 15 inundated for smaller return period flows. The 100-year flow values for Tippecanoe River, Clear

16 Creek, St. Joseph River and East Fork White River are obtained by fitting the Log-Pearson III 17 distribution (Bulletin 17b method) to the annual peak flow series at the corresponding USGS 18 gaging stations. The 100-year flow for the Brazos River reach is provided by the Fort Bend 19 County in Texas, and the flow data for Strouds Creek is provided by the North Carolina 20 Floodplain Mapping Program (NCFMP). Details about the study reaches including the geometry 21 data, 100-year flow values, LiDAR DEM resolution, slope and sinuosity are presented in Table

22 1. Additional topographic datasets used for Strouds Creek, Brazos River and East Fork White 
1 River study areas include NED $30 \mathrm{~m}$ and SRTM $90 \mathrm{~m}$ DEMs that are available from USGS

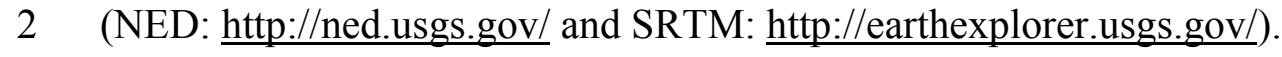

\section{Methodology}

4 To accomplish the three objectives listed in the Introduction section, the methodology includes

5 the following steps: (i) resampling of DEM data to create topographic datasets with varying

6 horizontal resolutions; (ii) introduction of errors corresponding to coarser resolution and vertical

7 accuracy into the resampled DEMs; (iii) flood modeling and inundation mapping using HEC-

8 GeoRAS and HEC-RAS; (iv) development and validation of the relationships between the DEM

9 properties (horizontal resolution and vertical accuracy), and flood inundation map extent. Figure

102 shows the LiDAR DEMs with cross-sectional configuration for the reaches used in this study.

11 Resampling of Topographic datasets

12 The high resolution LiDAR DEMs for all study areas are resampled into coarser resolution

13 DEMs by using the nearest neighbor resampling technique in ArcGIS. The original $6 \mathrm{~m}$

14 resolution LiDAR for Strouds Creek is resampled into DEMs of grid sizes ranging from $9 \mathrm{~m}$ -

$15100 \mathrm{~m}$. Similarly, the original $3 \mathrm{~m}$ resolution LiDAR DEMs for Tippecanoe River, St. Joseph

16 River, East Fork White River and Brazos River are resampled into DEMs of grid sizes ranging

17 from $6 \mathrm{~m}-100 \mathrm{~m}$. Among the study areas, Clear Creek reach in Iowa is excluded from 18 resampling because this reach is used for validation of the results from this study.

\section{Introduction of DEM errors}


1 Two types of errors are considered in this study including those arising from resampling of a

2 DEM from a finer to coarser resolution, and those arising from data sources (e.g., measurement

3 error). The error related to resampling can be estimated by computing Root Mean Square Error

4 (RMSE) for each of the resampled raster with respect to the original LiDAR DEM in order to

5 report a single global elevation error statistic for the entire DEM (Fisher \& Tate, 2006). All

6 resampled DEMs will have this error. DEM accuracy measurements standards provided by the

7 National Standards for Spatial Data Accuracy (NSSDA) state that the DEM errors follow a

8 normal distribution which is a fair assumption for an open terrain with residual errors lying

9 within 95\% confidence intervals (Aguilar et al., 2007; FGDC, 1998; Flood, 2004). To create a

10 normally distributed error surface, the mean and standard deviation of the errors are needed. The

11 RMSE of the resampled DEMs for each study area is used as the mean, and the standard

12 deviation is computed by taking the difference in elevations between resampled DEMs and

13 LiDAR DEM. This error raster is then added to all resampled DEMs using ArcGIS Spatial

14 Analyst toolbox to represent raster datasets that have both resampling and vertical errors.

15 Hydraulic modeling and flood inundation mapping

16 After incorporating resampling and/or vertical errors, all resampled raster datasets are then used

17 to create a 1D HEC-RAS (USACE, 2010) model by using HEC-GeoRAS (Ackerman, 2009) tool

18 in ArcGIS. HEC-RAS is the most commonly used flood modeling tool in the United States. The

19 use of a $1 D$ model for simulating the 100-year flow is justified because during such high flow

20 conditions, both the main channel and the floodplain are completely inundated with no storage

21 areas in the floodplain and the entire floodplain acts as a single channel. All simulations are

22 conducted by assuming a steady-state, which is typical for simulating the 100-year design flow in 
1 practice. The HEC-RAS models for all the reaches were previously calibrated and used for

2 creating the 100-year flood inundation maps so the boundary conditions and Manning's $n$ values

3 in these models are used without any modification. The HEC-RAS parameters are kept

4 unchanged for different DEMs because the goal is to investigate the sensitivity of inundation

5 maps to topographic errors instead of trying to create a new calibrated model for each

6 topographic dataset. After HEC-RAS simulations, the output files are imported into ArcGIS

7 using HEC-GeoRAS for creating flood inundation maps.

9 Development of relationships between DEM attributes and Hydraulic Outputs

10 Once the flood inundation maps for all raster datasets are obtained, the average water surface

11 elevation and the inundation area corresponding to each raster input are computed. The water

12 surface elevation and the inundation area obtained from DEMs of different resolutions and

13 vertical errors are then regressed against DEM cell size to establish a relationship between DEM

14 size (resolution) and hydraulic outputs. Finally, the relationships that are developed between

15 DEM attributes and hydraulic outputs are validated by investigating whether the flood inundation

16 maps developed from coarser resolution DEMs can be improved by using this information.

\section{Results}

18 In order to analyze the results, the study reaches are classified into two groups based on the land

19 use and size of the reach. Group A includes Strouds Creek, Tippecanoe River and St. Joseph

20 River, which are relatively smaller reaches surrounded by urban areas. Group B includes East

21 Fork White River and Brazos River, which are relatively large reaches surrounded by

22 agricultural areas. Generally the flood losses are higher in urban areas compared to 
1 rural/agricultural areas. Similarly, the flood extent is larger for larger river reaches compared to

2 smaller reaches. Putting the data into these broad groups will provide a context to look at the

3 relative impact of topography on hydraulic outputs for the study reaches.

\section{$4 \quad$ Error from resampling of DEMs}

5 After the DEMs are resampled into different resolutions, RMSE is computed for each DEM with

6 respect to the LiDAR DEM. RMSE for all river reaches included in the study increases with

7 decreasing DEM resolutions as shown in Figure 3. The magnitude of RMSE is found to be

8 related to the slope of the terrain and the size of the study area. For example, Strouds Creek had

9 the largest RMSE of $0.69 \mathrm{~m}$ for a $24 \mathrm{~m}$ DEM compared to that for Tippecanoe River (RMSE $=$

$100.44 \mathrm{~m})$ and St. Joseph River $(\mathrm{RMSE}=0.38 \mathrm{~m})$. The difference between predicted elevations

11 using a LiDAR and coarser resolution DEMs decreases for larger reaches with relatively flat

12 terrain as shown by a smaller RMSE $(0.24 \mathrm{~m})$ for a $24 \mathrm{~m}$ DEM for East Fork White River and

13 Brazos River $(\mathrm{RMSE}=0.25 \mathrm{~m})$. The RMSE has a linear relationship with grid size $\left(\mathrm{R}^{2}>95 \%\right)$

14 which suggests that DEM resolution has a significant effect on the accuracy of topographic

15 datasets. The RMSE for a $9 \mathrm{~m}$ DEM for Strouds Creek is $0.34 \mathrm{~m}$ as compared to $0.80 \mathrm{~m}$ for a 30

$16 \mathrm{~m}$ DEM which is a significant decrease in the accuracy of the dataset due to resampling.

17 The slope of the linear trend lines for the reaches presented in Figure 3 suggest that DEM errors

18 are higher in magnitude for Strouds Creek, which has urban land use with high spatial variability

19 of elevations when compared to larger reaches with agricultural land use. The linear trend lines

20 also suggest that the effect of coarser resolution DEMs on vertical accuracy is relatively smaller

21 for larger reaches with flat terrain. 
2 The water surface elevations for all cross-sections within a reach are averaged to produce one 3 mean water surface elevation (WSE) for a specific DEM resolution. Tables 2 and 3 present the

4 effect of DEM resolution on hydraulic model outputs including mean WSE and inundation area

5 for reaches in Group A and B, respectively. Figure 4 shows the relationship between mean WSE

6 and DEM resolution for Strouds Creek, Tippecanoe River and St. Joseph River; whereas Figure

75 shows the relationship between mean WSE and DEM resolution for East Fork White River and

8 Brazos River.

9 The mean WSE increases linearly with grid size for Strouds Creek, Tippecanoe River and St.

10 Joseph River. For example, the average water surface elevation for Strouds Creek increases

11 about $0.8 \mathrm{~m}$ and $2.96 \mathrm{~m}$ for the $30 \mathrm{~m}$ and $100 \mathrm{~m}$ resolution DEM respectively when compared to

12 the 6 m LiDAR DEM. Similarly, the inundation area increases linearly with DEM grid size. The

13 area of inundation increases about 13.8\% (60 m DEM) and 42.6\% (100 m DEM) for Tippecanoe

14 River, 7.6\% (30 m DEM) and 22\% (100 m DEM) for St. Joseph River when compared to the $3 \mathrm{~m}$

15 LiDAR DEMs. Overall, the regression equations between hydraulic outputs and grid size have

16 an $\mathrm{R}^{2}$ greater than $90 \%$ for the three study reaches in Group A suggesting a very good linear fit.

17 The inundation area is higher with a coarser resolution DEM compared to a finer resolution

18 DEM for the same number of inundated cells. As the DEM resolution becomes coarser, the

19 smoothening of the elevations raises the overall surface, which in turn leads to higher water

20 surface elevations and flood inundation extents (see Figure 4). The percentage change in

21 inundation is more for Strouds Creek with a small size and V-shaped valley when compared to

22 St. Joseph River which has a U-shaped valley to route more flow through the river than the 
1 floodplain. The effect of valley shape on the WSE and flood inundation extent is visible in

2 Figure 6 that shows one typical cross-section for each study reach. For two similarly sized

3 reaches, it would be reasonable to assume that as the DEM gets coarser, the results from a U

4 shaped valley to be similar from a V shape valley because the shape gets smoother with coarser

5 resolution. The results from Strouds Creek are more pronounced in this study because it is much

6 smaller compared to the St. Joseph River.

7 The effect of surrounding topography and valley shape is also visible for the White and Brazos

8 River. The change in mean WSE and inundation area for a $100 \mathrm{~m}$ DEM of East Fork White

9 River is relatively small in comparison to the results from the original $3 \mathrm{~m} \mathrm{LiDAR}$ DEM due to

10 its deep U-shaped valley and a highly elevated floodplain which causes most of the flow to be

11 routed through the main channel (see Figure 5 and 6). In the case of Brazos River, the flat terrain

12 and shallow main channel causes most of the water to flow through the floodplain. As a result, a

$130.5 \mathrm{~m}$ increase in mean WSE for the $100 \mathrm{~m}$ DEM causes an $18.26 \%$ increase in the inundation

14 area. The hydraulic outputs and DEM resolution have a linear relationship $\left(\mathrm{R}^{2}>90 \%\right)$ for both

15 East Fork White River and Brazos River. These results suggest that the linear relationship holds

16 true for all study reaches irrespective of the size and land use type.

17 Figure 6 also shows how the top width and water depth changes when the DEM resolution is

18 changed for all reaches. As mentioned earlier, the increase in WSE with coarser grid size is

19 mainly caused by the increase in the channel bed elevation from the smoothening effect due to

20 DEM resampling. This in turn causes the top width of the channel sections to increase with grid

21 size, thus directly affecting the flood inundation extent. For small study areas like Strouds Creek

22 and Tippecanoe River, the channel bed is not accurately represented by coarser resolution DEMs

23 and therefore, there is a significant loss in the topographical information from DEM resampling. 
1 For large rivers like Brazos River, the loss in topographic features is less significant due to the

2 larger width of the cross-sections. The inundation extents for the study areas produced using

3 DEMs of different grid sizes are presented in Figure 7, highlighting the impact of DEM

4 resolution on the quality of flood inundation maps.

6 Hydraulic modeling is also performed by using DEMs that are coarser and have vertical errors

7 arising from other sources such as measurement errors. The results presented in Figure 8 show

8 flood inundation area is again linearly related to the vertical error. The slope of the linear fit

9 between mean WSE and vertical error is steeper compared to the fit between DEM resolution

10 and WSE. This is expected because these DEMs have both the resampling error and the vertical

11 error. Strouds Creek is the most affected reach among all the study reaches, and it shows an

12 increase of $3.6 \mathrm{~m}$ in the average WSE and $113 \%$ increase in the inundation area from a $80 \mathrm{~m}$

13 DEM compared to the original $6 \mathrm{~m}$ LiDAR DEM.

14 The inundation area for Strouds Creek slightly decreases for $9 \mathrm{~m}, 12 \mathrm{~m}, 18 \mathrm{~m}$ and $21 \mathrm{~m}$ DEMs

15 containing errors as shown in Figure 8 . This can be attributed to the random nature of normally

16 distributed errors which can cause significant variation in the topography for smaller cell sizes

17 resulting in large number of spikes in elevation. These spikes create depressions leading to a

18 decrease in predicted area of inundation. However, these variations are very small in magnitude,

19 thus the overall effect of error addition results in an increase in the magnitude of the predicted

20 hydraulic outputs. Addition of error also leads to a loss in channel bed's longitudinal profile for

21 coarser DEMs due to the large magnitude and standard deviations of these errors, thus reducing

22 the accuracy of prediction and quality of flood maps as shown in Figures 9 and 10. 
1 The results of the linear regression analysis for the five river reaches, presented in Figures 4, 5

2 and 8, show that within a specific range of grid size, the mean WSE and flood inundation area

3 have linear relationships with DEM resolution and vertical error. The question then is: can these

4 linear relationships be exploited to improve hydraulic model outputs and flood inundation areas

5 where only coarser resolution DEMs with high vertical errors are available? This question is

6 explored in the next section.

$7 \quad$ Validation of linear relationship between DEM attributes and hydraulic model outputs

8 If linear relationships exist between DEM attributes (resolution and error) and mean WSE, it is

9 possible that this relationship can be extrapolated to get WSE for any specified grid size or

10 vertical error. Whether or not such an extrapolation will give better flood inundation maps from

11 coarser resolution DEMs is tested in this section. Three different combinations of DEM attributes

12 and sources are considered for validation. In part (i), a coarser resolution $30 \mathrm{~m}$ LiDAR DEM for

13 Clear Creek without any measurement error is used to account for only errors due to horizontal

14 resolution. In part (ii), a coarser resolution $30 \mathrm{~m}$ LiDAR DEM for Strouds Creek with additional

15 measurement error is used to account for errors due to both horizontal resolution and vertical

16 accuracy. In part (iii), two USGS NED $30 \mathrm{~m}$ resolution DEMs for East Fork White River and

17 Strouds Creek along with two SRTM 90 m resolution DEMs for Strouds Creek and Brazos River

18 are used to account for errors due to horizontal resolution, vertical accuracy and source of 19 datasets.

(i) Validation using coarser resolution DEMs without measurement error 
1 The goal of this validation is to see if a $30 \mathrm{~m}$ DEM is available for Clear Creek, can it give

2 results are that are comparable to the results from a LiDAR DEM. First, linear relationships for

3 all cross-sections are developed between the DEM resolution and WSE for four additional DEMs

4 with grid sizes equal to $48,60,70$ and $80 \mathrm{~m}$ that are created by resampling the $30 \mathrm{~m}$ DEM (Table

54 and Figure 11). These linear relationships are then extrapolated to estimate WSE corresponding

6 to a $3 \mathrm{~m}$ resolution DEM as shown in Figure 11. Sample estimates of WSE obtained using the

7 linear relationship for six cross-section stations are presented in Table 4. A $3 \mathrm{~m}$ resolution DEM

8 is used for extrapolation to enable comparison with the results obtained by using the LiDAR

9 DEM at the same resolution. The results of this comparison are presented in Figure 12.

10 Using the same technique, water surface elevations are predicted for Strouds Creek, Tippecanoe

11 River, St. Joseph River, East Fork White River and Brazos River and the results are compared to

12 the LiDAR outputs (see Figure 13). The RMSE in WSE between the extrapolated values by

13 using coarser resolution DEM and those obtained by using the LiDAR are presented in Table 5

14 for all the sites. The water surface elevations for Strouds Creek, East Fork White River, Clear

15 Creek and Brazos River match well with the LiDAR results with no significant outliers. The

16 water surface elevations for Tippecanoe River and St. Joseph River are slightly under-predicted

17 with some outliers. This under prediction can be explained by using the grid size versus WSE

18 plots in Figure 4. During the validation, the linear relationships are essentially developed by

19 using the points corresponding to a grid sizes greater than $30 \mathrm{~m}$. As seen in Figure 4 (b-c), these

20 points will create a slightly steeper slope which will result in a under predicted WSE for a

21 smaller grid size. The cause for steeper slope at larger grid size can be attributed to the loss of

22 bathymetry and floodplain details for smaller size reaches. Despite this slight under prediction, 
1 the overall results suggest that this approach can be used to get a better WSE estimate from a

2 coarser resolution DEM thus reducing the effect of DEM resolution on hydraulic modeling.

(ii) Validation using Coarser Resolution Datasets with vertical errors

4 In this validation, additional vertical error is added to the coarser resolution $30 \mathrm{~m}$ LiDAR DEM

5 for Strouds Creek by creating and adding an error distribution dataset using the RMSE presented

6 in Figure 3. A linear relationship is developed and extrapolated to get WSE at a smaller

7 resolution DEM. Sample results for Strouds Creek are shown in Figure 14. The RMSE of

8 predicted water surface elevations using a $30 \mathrm{~m}$ resampled DEM with error is reduced from 5.37

$9 \mathrm{~m}$ to $0.68 \mathrm{~m}$ using the new approach and the water surface profile is comparable to that from

10 LiDAR results for Strouds Creek. Figure 14 shows the comparison in the water surface

11 elevations and water surface profiles for the $30 \mathrm{~m}$ DEM containing errors, predicted profile using

12 the new approach and the LiDAR (base) results for Strouds Creek.

13 The validation results presented until now used a coarser resolution DEM that is created by

14 resampling a finer resolution LiDAR DEM. The quality of these DEMs is relatively better

15 compared to what one would get from public domain such as from USGS NED or SRTM

16 datasets. Will the validation results be different if a public domain DEM such as a $30 \mathrm{~m}$ DEM

17 from USGS or $90 \mathrm{~m}$ SRTM DEM is used? This is verified in the next section.

(iii) Validation using Public Domain Datasets

19 In this section, the validation is carried out by using two public domain datasets, USGS $30 \mathrm{~m}$

20 NED and SRTM $90 \mathrm{~m}$ DEM. It is assumed that the public domain datasets have errors from both 
1 being coarse and source errors arising from measurements, interpolation techniques and

2 information loss. First, the error associated with both the NED and SRTM datasets is computed

3 in the form of RMSE by using the LiDAR datasets for Strouds Creek, White River and Brazos

4 River. Next, the $30 \mathrm{~m}$ NED and $90 \mathrm{~m}$ SRTM DEMs are used to create coarser resolution DEMs

5 through resampling and linear propagation of DEM errors. This is done by evaluating the RMSE

6 for these datasets by selecting a set of points in the floodplain and using the linear relationship of

7 RMSE with grid size to create normally distributed error datasets which are added to resampled

8 coarser resolution DEMs. These modified datasets are then used to develop linear regression

9 equations, which are then extrapolated to estimate WSE corresponding to a finer resolution

10 DEM. These WSE estimates and the WSE that one would get by using just the $30 \mathrm{~m}$ NED and 90

11 m SRTM DEMs are then compared to the results obtained from LiDAR as shown in Figure 15.

12 The WSE estimates obtained through extrapolation of linear relationship are significantly better

13 compared to that from just using the public domain DEMs. The WSE is improved by $40 \%$ in

14 terms of RMSE for East Fork White River and by 36\% for Strouds Creek. The improvement is

15 even more substantial for the SRTM DEM. For example, the WSE estimates improved by $51 \%$

16 for Brazos River and 65\% for Strouds Creek. This analysis suggests that the initial quality of

17 topographic datasets and existing error also impacts the accuracy of the WSE results obtained

18 using the linear regression. For Strouds Creek, a $30 \mathrm{~m}$ resampled DEM (RMSE $=0.8 \mathrm{~m})$ derived

19 from LiDAR data produces better WSE estimates using this approach than a $30 \mathrm{~m}$ NED DEM

$20 \quad(\mathrm{RMSE}=1.5 \mathrm{~m})$ and a $90 \mathrm{~m}$ SRTM DEM $(\mathrm{RMSE}=4.6 \mathrm{~m})$. 


\section{Summary and Conclusions}

2 Topographic datasets play a significant role in hydraulic modeling and the accurate prediction of

3 flood inundation areas. Even though LiDAR data are highly accurate, hydraulic modeling and

4 flood inundation mapping is still carried out using datasets obtained from other sources that are

5 less accurate due to the cost in obtaining LiDAR data. DEM resolution and error are two main

6 attributes that affect the hydraulic modeling results, and many studies have concluded that flood

7 inundation mapping results can be improved using only high quality topographic data. The

8 accuracy of hydraulic modeling using coarser resolution DEMs that are widely available across

9 the globe can be improved using the approach developed in this study if accurate modeling of

10 spatial distributions of DEM errors is carried out. The current methods used for DEM error

11 analysis are too complicated and their application for hydraulic modeling purposes relies heavily

12 on detailed topographic surveys. Therefore, a simpler approach is used in this study which uses

13 normally distributed DEM errors. This study addresses the challenges of hydraulic modeling

14 using low quality data and focuses on using the relationship between DEM attributes and

15 hydraulic outputs to reduce the impact of coarser resolution and vertical errors in DEMs.

16 The following conclusions are drawn from this study:

17 1. A comparison of RMSE of resampled topographic datasets with grid size shows that the 18 amount of error increases with decreasing DEM resolution. The five study reaches used 19 in this study show a strong positive linear relationship $\left(\mathrm{R}^{2}>90 \%\right)$ between resampling $20 \quad$ error and grid size. 
12 2. For the same set of boundary conditions and flow, the mean WSE also show a strong

2 positive linear relationship with DEM grid size for all the areas used in the study.

3 3. The predicted flood inundation areas for all the study reaches increase with decreasing 4 DEM resolution. This suggests that DEMs of coarser resolution over-predict the flood extent. The flood inundation area also shows a strong positive linear relationship with the grid size.

4. The shape of the valleys and channel slope determine the extent to which DEM resampling affects the inundation results. DEM resampling and vertical error introduction

5. The results also indicate that smaller reaches with higher urban land cover and spatial variability have higher slopes for the linear regression curves. Sites with higher urban cover such as Strouds Creek have steeper regression slopes when compared to Brazos River which has agricultural land cover and a flat terrain.

6. The results from this study are most influenced by the shape and slope of the main channel because of their greater impact on the WSE and inundation area. The terrain and width of the floodplain also influenced the percentage change in hydraulic outputs for different DEM resolutions. Overall, small reaches with steeper channel slope, bank slope and urban land use are influenced more by DEM resolution and accuracy. 
7. Results from this study show that the linear relationship between the DEM attributes and WSE can be exploited to improve flood inundation maps obtained from coarser and less accurate DEMs. Application of this approach shows that the existing error in the dataset plays a major role in the overall quality of the final result. For example, when a $30 \mathrm{~m}$ DEM that is resampled from a LiDAR DEM is used, the results obtained from using the linear regression are much better compared to that from a public domain $30 \mathrm{~m}$ NED DEM.

8. Further validation using $30 \mathrm{~m}$ NED and $90 \mathrm{~m}$ SRTM DEM show that the use of regression equation produces significant improvement in WSE estimates. However, the improvement in the WSE and its application to obtain better flood inundation maps is dependent on the study reach characteristics such as its reach length and width.

This study provides a methodology for improving hydraulic modeling results and mapping of flood inundation extents in areas where only coarser resolution topography data or DEMs are available. By replicating the methodology presented here, relationships between DEM properties and flood modeling results can be developed, and possibly regionalized. Such regional relationships can be used to improve flood modeling results and create better flood inundation maps where finer resolution DEMs do not exist. Similarly, the methodology presented in this study can also be modified to understand the relationship between the DEM properties and the inundation extent without conducing any hydraulic modeling. For example, for a given water surface, how does the inundation extent changes for different resolution DEMs? If this is known, one could just apply a correction to the hydraulic modeling results to get water surface elevations that may correspond to a better quality DEM. 
1 A high resolution LiDAR DEM can provide a very accurate representation of floodplain, but the

2 river bathymetry is still absent in a LiDAR DEM. Inclusion of bathymetry for Tippecanoe River

3 and St. Joseph (results not included) showed the final form of linear relationship is not very

4 different because as the DEM becomes coarser the bathymetry details are lost during resampling.

5 However, the results from using the bathymetry will be better compared to the results from just

6 the LiDAR DEM. Another important consideration is the creation of coarser resolution DEMs

7 through resampling. This study used the nearest neighbor resampling method for resampling all

8 DEMs. If a different method such as bilinear or cubic resampling is used, the results will be

9 slightly different, but not significant. For example, the WSE for Strouds Creek changed by less

10 than $0.1 \mathrm{~m}$ when the bilinear or cubic resampling is used.

11 Future work on hydraulic modeling and flood inundation mapping should consider the optimum

12 representation of the spatial characteristics of DEM errors since accurate flood extents can be

13 obtained from WSE by removing DEM errors. Further studies may look into the application of

14 the rating relationships developed between vertical elevation errors and spatial variability by

15 Heritage et al. (2009). Similarly, more study areas should be examined to establish the validity of

16 the relationships developed including arid regions of the western United States. Most flood

17 studies in the U.S. and other parts of the world still use HEC-RAS 1D model for flood inundation

18 mapping so the results from this study are useful to create improved results in data sparse

19 regions. The results from other $1 D$ and $2 D$ hydraulic models may differ from HEC-RAS models

20 and further investigation is required to validate the applicability of these results for those

21 models. Future studies should include the use of a $2 D$ hydrodynamic model to determine the

22 effect of DEM resolution and DEM errors on water surface elevations and flood inundation

23 maps. 


\section{Acknowledgements}

2 This work was supported by grants from the United States Geological Survey (USGS) and the 3 Indiana Office of Community and Rural Affairs. We thank the Indiana Water Science center for

4 providing the data for Indiana Reaches, the North Carolina Floodplain Mapping Program for

5 Strouds Creek data, the Fort Bend County office for the Brazos River data, and the Iowa Flood

6 Center for the Clear Creek data. We also thank the associate editor and two anonymous

7 reviewers of this manuscript for providing constructive comments on the previous version of this 8 manuscript. 
Ackerman, C. (2009). HEC-GeoRAS-GIS Tools for Support of HEC-RAS using ArcGIS, User's Manual. US Army Corps of Engineers-Hydrologic Engineering Center (HEC), 4.2(September).

Aguilar, F. J., Aguilar, M. A., \& Agüera, F. (2007). Accuracy assessment of digital elevation models using a non-parametric approach. International Journal of Geographical Information Science, 21(6), 667-686.

Aguilar, F. J., Mills, J. P., Delgado, J., Aguilar, M. A., Negreiros, J. G., \& Pérez, J. L. (2010). Modelling vertical error in LiDAR-derived digital elevation models. ISPRS Journal of Photogrammetry and Remote Sensing, 65, 103-110.

Aycock, W. C., \& Wang, Y. (2004). Comparison of the New Digital Flood Insurance Map (DFIRM) with the Existing FIRM, Wilson, North Carolina. Southeastern Geographer, 44(2), 159-169.

Bater, C. W., \& Coops, N. C. (2009). Evaluating error associated with LiDAR-derived DEM interpolation. Computers \& Geosciences, 35, 289-300.

Bates, P. D., Marks, K. J., \& Horritt, M. S. (2003). Optimal use of high-resolution topographic data in flood inundation models. Hydrological Processes, 17, 537-557.

Brandt, S. (2005). Resolution issues of elevation data during inundation modeling of river floods. Proceedings of the XXXI International Association of Hydraulic Engineering and Research Congress (IAHR), 3573-3581.

Burrough, P. A. (1986). Principles of geographical information systems for land resources assessment. Geocarto International, 1(3), 54-54.

Carlisle, B. H. (2005). Modelling the Spatial Distribution of DEM Error. Transactions in GIS, 9(4), 521-540.

Casas, A., Benito, G., Thorndycraft, V. R., \& Rico, M. (2006). The topographic data source of digital terrain models as a key element in the accuracy of hydraulic flood modelling. Earth Surface Processes and Landforms, 31, 444-456.

Chaplot, V., Darboux, F., Bourennane, H., Leguédois, S., Silvera, N., \& Phachomphon, K. (2006). Accuracy of interpolation techniques for the derivation of digital elevation models in relation to landform types and data density. Geomorphology, 77, 126-141. 
Charlton, M. E., Large, a. R. G., \& Fuller, I. C. (2003). Application of airborne LiDAR in river environments: the River Coquet, Northumberland, UK. Earth Surface Processes and Landforms, 28, 299-306.

Cook, A., \& Merwade, V. (2009). Effect of topographic data, geometric configuration and modeling approach on flood inundation mapping. Journal of Hydrology, 377, 131-142.

Erdoğan, S. (2010). Modelling the spatial distribution of DEM error with geographically weighted regression: An experimental study. Computers \& Geosciences, 36(1), 34-43.

FGDC. (1998). Geospatial Positioning Accuracy Standards Part 3: National Standard for Spatial Data Accuracy. U.S. Federal Geographic Data Committee.

Fisher, P. F., \& Tate, N. J. (2006). Causes and consequences of error in digital elevation models. Progress in Physical Geography, 30, 467-489.

Flood, M. (2004). ASPRS Guidelines Vertical Accuracy Reporting for LiDAR Data. American Society for Photogrammetry and Remote Sensing, 1-20.

Gallant, J. C., \& Hutchinson, M. F. (1997). Scale dependence in terrain analysis. Mathematics and Computers in Simulation, 43, 313-321.

Gesch, D. B. (2007). Chapter 4 - The National Elevation Dataset, in Maune, D., ed., Digital Elevation Model Technologies and Applications: The DEM Users Manual, 2nd Edition: Bethesda, Maryland. American Society for Photogrammetry and Remote Sensing, 99-118.

Giglierano, J. D. (2010). LiDAR basics for natural resource mapping applications. Geological Society, London, Special Publications, 345(1), 103-115.

Gonga-Saholiariliva, N. (2011). Techniques for quantifying the accuracy of gridded elevation models and for mapping uncertainty in digital terrain analysis. Progress in Physical Geography. 35(6), 739-764.

Haile, A., \& Rientjes, T. (2005). Effects of LiDAR DEM Resolution in Flood Modelling: A Model Sensitivity Study for the City of Tegucigalpa, Honduras. ISPRS WG III/3, III/4 V/3 Workshop "Laser Scanning 2005", 168-173.

Hall, J. W., Tarantola, S., Bates, P. D., \& Horritt, M. S. (2005). Distributed Sensitivity Analysis of Flood Inundation Model Calibration. Journal of Hydraulic Engineering, 131(February), $117-126$.

Heritage, G. L., Milan, D. J., Large, A. R. G., \& Fuller, I. C. (2009). Influence of survey strategy and interpolation model on DEM quality. Geomorphology, 112, 334-344. 
Hodgson, M. E., \& Bresnahan, P. (2004). Accuracy of Airborne LiDAR-Derived Elevation: Empirical Assessment and Error Budget. Photogrammetric Engineering \& Remote Sensing, 70(3), 331-339.

Hodgson, M. E., Jensen, J. R., Schmidt, L., Schill, S., \& Davis, B. (2003). An evaluation of LiDAR- and IFSAR-derived digital elevation models in leaf-on conditions with USGS Level 1 and Level 2 DEMs. Remote Sensing of Environment, 84(2), 295-308.

Höhle, J., \& Höhle, M. (2009). Accuracy assessment of digital elevation models by means of robust statistical methods. ISPRS Journal of Photogrammetry and Remote Sensing, 64(4), 398-406.

Hu, P., Liu, X., \& Hu, H. (2009). Accuracy Assessment of Digital Elevation Models based on Approximation Theory. Photogrammetric Engineering \& Remote Sensing, 75(1), 49-56.

Jung, Y., \& Merwade, V. (2011). Uncertainty Quantification in Flood Inundation Mapping Using Generalized Likelihood Uncertainty Estimate and Sensitivity Analysis. Journal of Hydrologic Engineering, ASCE 2012, 17(4), 507-520.

Kenward, T., Lettenmaier, D., Wood, E. F., \& Fielding, E. (2000). Effects of Digital Elevation Model Accuracy on Hydrologic Predictions. Remote Sensing of Environment, 74, 432-444.

Li, J., \& Wong, D. W. S. (2010). Effects of DEM sources on hydrologic applications. Computers, Environment and Urban Systems, 34(3), 251-261.

Lin, S., Jing, C., Coles, N. A., Chaplot, V., Moore, N. J., \& Wu, J. (2012). Evaluating DEM source and resolution uncertainties in the Soil and Water Assessment Tool. Stochastic Environmental Research and Risk Assessment, 27(1), 209-221.

Marks, K., \& Bates, P. (2000). Integration of high-resolution topographic data with floodplain flow models. Hydrological Processes, 14(July 1998), 2109-2122.

Merwade, V. (2009). Effect of spatial trends on interpolation of river bathymetry. Journal of Hydrology, 371(1-4), 169-181.

Merwade, V., Cook, A., \& Coonrod, J. (2008). GIS techniques for creating river terrain models for hydrodynamic modeling and flood inundation mapping. Environmental Modelling \& Software, 23(10-11), 1300-1311.

Merwade, V., Olivera, F., Arabi, M., \& Edleman, S. (2008). Uncertainty in Flood Inundation Mapping: Current Issues and Future Directions. Journal of Hydrologic Engineering, 13(7), 608-620. 
Omer, C., Nelson, E., \& Zundel, A. (2003). Impact of Varied Data Resolution on Hydraulic Modeling and Floodplain Delineation. Journal of the American Water Resources Association (JAWRA), 39(2), 467-475.

Pappenberger, F., Beven, K., Horritt, M., \& Blazkova, S. (2005). Uncertainty in the calibration of effective roughness parameters in HEC-RAS using inundation and downstream level observations. Journal of Hydrology, 302, 46-69.

Pappenberger, F., Matgen, P., Beven, K. J., Henry, J.-B., Pfister, L., \& Fraipont, P. (2006). Influence of uncertain boundary conditions and model structure on flood inundation predictions. Advances in Water Resources, 29(10), 1430-1449.

Raber, G. T., Jensen, J. R., Hodgson, M. E., Tullis, J. A., Davis, B. A., \& Berglund, J. (2007). Impact of LiDAR Nominal Post-spacing on DEM Accuracy and Flood Zone Delineation. Photogrammetric Engineering \& Remote Sensing, 73, 793-804.

Rayburg, S., Thoms, M., \& Neave, M. (2009). A comparison of digital elevation models generated from different data sources. Geomorphology, 106, 261-270.

Rutter, H. K., Newsham, R., Morris, D. G., \& McKenzie, A. A. (2010). Selecting the appropriate digital terrain model: an example from a hazard mapping exercise. Geological Society, London, Special Publications, 345(1), 67-74.

Sanders, B. F. (2007). Evaluation of on-line DEMs for flood inundation modeling. Advances in Water Resources, 30(8), 1831-1843.

Schumann, G., Matgen, P., Cutler, M. E. J., Black, A., Hoffmann, L., \& Pfister, L. (2008). Comparison of remotely sensed water stages from LiDAR, topographic contours and SRTM. ISPRS Journal of Photogrammetry and Remote Sensing, 63(3), 283-296.

Smith, M. J. (2010). Digital elevation models for research: UK datasets, copyright and derived products. Geological Society, London, Special Publications, 345(1), 129-133.

Smith, S., Holland, D., \& Longley, P. (2004). The importance of understanding error in LiDAR Digital Elevation Models. Proceedings of XXth ISPRS Conference.

Snyder, G. I. (2012). National Enhanced Elevation Assessment at a Glance. U.S. Geological Survey Fact Sheet 2012, 3088, http://pubs.usgs.gov/fs/2012/3088/.

Srinivas, K., Werner, M., \& Wright, N. (2008). Comparing forecast skill of inundation models of differing complexity: The case of Upton upon Severn. Flood Risk Management: Research and Practice, (October), 85-94. 
Stal, C., Nuttens, T., Bourgeois, J., Carlier, C., De Maeyer, P., \& De Wulf, A. (2011). Accuracy assessment of a LiDAR Digital Terrain Model by using RTK GPS and total station. EARSeL eProceedings, 10(8), 1-8.

Straatsma, M., \& Huthoff, F. (2011). Uncertainty in 2D hydrodynamic models from errors in roughness parameterization based on aerial images. Physics and Chemistry of the Earth, 36, $324-334$.

Tate, E. C., Maidment, D. R., Olivera, F., \& Anderson, D. J. (2002). Creating a Terrain Model for Floodplain Mapping. Journal of Hydrologic Engineering, 7, 100-108.

U.S. Army Corps of Engineers. (2010). HEC-RAS River Analysis System Hydraulic Reference Manual. Version 4.1. Hydrologic Engineering Center, Davis, California, 411p.

Wang, Y., \& Zheng, T. (2005). Comparison of Light Detection and Ranging and National Elevation Dataset Digital Elevation Model on Floodplains of North Carolina. Natural Hazards Review-ASCE, 6(1), 34-40.

Werner, M. G. F. (2001). Impact of Grid Size in GIS Based Flood Extent Mapping Using 1-D Flow Model. Physics and Chemistry of Earth (B). 26, 517-522.

Werner, M. G. F., Hunter, N. M., \& Bates, P. D. (2005). Identifiability of distributed floodplain roughness values in flood extent estimation. Journal of Hydrology, 314, 139-157.

Wise, S. (2011). Cross-validation as a means of investigating DEM interpolation error. Computers \& Geosciences, 37(8), 978-991.

Yue, T.-X., Du, Z.-P., Song, D.-J., \& Gong, Y. (2007). A new method of surface modeling and its application to DEM construction. Geomorphology, 91(1-2), 161-172. 


\section{Table Captions}

2 Table 1. Details of flow and geometry data

3 Table 2. Effect of DEM resolution on hydraulic outputs for small reaches with urban land use

4 Table 3. Effect of DEM resolution on hydraulic outputs for large reaches with agricultural land 5 use

6 Table 4. Validation results for Clear Creek

7 Table 5. RMSE of WSE between extrapolated values by using coarser resolution DEM and

8 those obtained by using the LiDAR 
Figure Captions

2 Figure 1. Layout map of study areas

3 Figure 2. LiDAR DEMs with cross-sectional configuration, (a) Strouds Creek; (b) Tippecanoe

4 River; (c) St. Joseph River; (d) East Fork White River; (e) Clear Creek; and (f) Brazos River

5 Figure 3. RMSE versus grid size for Strouds Creek, Tippecanoe River, St. Joseph River, East

6 Fork White River and Brazos River

7 Figure 4. Average WSE and Inundation area versus grid size, (a) Strouds Creek; (b) Tippecanoe

8 River; and (c) St. Joseph River

9 Figure 5. Average WSE and Inundation area versus grid size, (a) East Fork White River; and (b)

10 Brazos River

11 Figure 6. Cross-sectional profiles for LiDAR and $100 \mathrm{~m}$ DEMs with Elevation (m) on y-axis and

12 Station (m) on x-axis, (a) Strouds Creek; (b) Tippecanoe River; (c) St. Joseph River; (d) East

13 Fork White River; and (e) Brazos River

14 Figure 7. Comparison of LiDAR and $100 \mathrm{~m}$ flood maps, (a) Strouds Creek; (b) Tippecanoe

15 River; (c) St. Joseph River; (d) East Fork White River; and (e) Brazos River

16 Figure 8. Hydraulic outputs versus grid size comparisons for DEMs containing errors and

17 resampled DEMs (Strouds Creek)

18 Figure 9. Cross-sectional profiles comparisons for LiDAR and $100 \mathrm{~m}$ DEM containing error

19 (Strouds Creek)

20 Figure 10. Comparison of flood maps between LiDAR and DEMs with errors (Strouds Creek)

21 Figure 11. Extrapolation of linear regression results for validation (Clear Creek)

22 Figure 12. Predicted versus LiDAR WSE and water surface profile comparison (Clear Creek)

23 Figure 13. Predicted versus LiDAR WSE, (a) Strouds Creek; (b) Tippecanoe River; (c) St.

24 Joseph River; (d) East Fork White River; and (e) Brazos River

25 Figure 14. Comparison of WSE and water surface profile for $30 \mathrm{~m} \mathrm{DEM}$ with error and

26 predicted results with respect to LiDAR (Strouds Creek)

27 Figure 15. Predicted and original WSE versus LiDAR WSE, (a) Strouds Creek USGS; (b) East

28 Fork White River USGS; (c) Strouds Creek SRTM; and (d) Brazos River SRTM 
Tables

Table 1. Details of flow and geometry data

\begin{tabular}{|c|c|c|c|c|c|}
\hline Study Area & $\begin{array}{c}\text { DEM } \\
\text { Resolution } \\
\text { (m) }\end{array}$ & LiDAR DEM Source & $\begin{array}{l}\text { No. of Cross } \\
\text { Sections }\end{array}$ & $\begin{array}{c}100-y r \text { Flow } \\
\text { Value } \\
\left(\mathrm{m}^{3} / \mathrm{s}\right)\end{array}$ & $\begin{array}{c}\text { Reach } \\
\text { Length } \\
(\mathrm{km})\end{array}$ \\
\hline Strouds Creek & 6 & NCFMP & 50 & 103 & 6.5 \\
\hline Tippecanoe River & 3 & USGS Indiana Water Science Center & 46 & 366 & 10.4 \\
\hline St. Joseph River & 3 & USGS Indiana Water Science Center & 52 & 606 & 11.2 \\
\hline East Fork White River & 3 & USGS Indiana Water Science Center & 56 & 3,673 & 20.2 \\
\hline Clear Creek & 1 & Iowa Flood Center & 86 & 287 & 39.0 \\
\hline Brazos River & 3 & Fort Bend County, Texas & 46 & 3,061 & 59.9 \\
\hline Study Area & $\begin{array}{c}\text { Drainage Ar } \\
\qquad\left(\mathrm{km}^{2}\right)\end{array}$ & Landuse/Landform & & Channel Slope & Sinuosity \\
\hline Strouds Creek & 170 & \multicolumn{2}{|l|}{ Urban/V-shaped valleys } & 0.00562 & Low \\
\hline Tippecanoe River & 2440 & \multicolumn{2}{|c|}{ Urban/Shallow meandering valleys } & 0.00025 & High \\
\hline St. Joseph River & 8728 & \multicolumn{2}{|l|}{ Urban/U-shaped valleys } & 0.00018 & Moderate \\
\hline East Fork White River & 10,000 & \multicolumn{2}{|c|}{ Agricultural/U-shaped valleys } & 0.00001 & Moderate \\
\hline Clear Creek & 255 & \multicolumn{2}{|c|}{ Agricultural/U-shaped valleys } & 0.00079 & Low \\
\hline Brazos River & 116,827 & \multicolumn{2}{|c|}{ Agricultural/Shallow meandering valleys } & 0.00009 & High \\
\hline
\end{tabular}


Table 2. Effect of DEM resolution on hydraulic outputs for small reaches with urban land use

\begin{tabular}{|cccc|cccc|cccc|}
\hline \multicolumn{4}{c}{ Strouds Creek } & \multicolumn{5}{c|}{ Tippecanoe River } & \multicolumn{4}{c|}{ St. Joseph River } \\
\hline $\begin{array}{c}\text { Grid } \\
\text { Size }\end{array}$ & $\begin{array}{c}\text { Avg. } \\
\text { WSE }\end{array}$ & $\begin{array}{c}\text { Inundation } \\
\text { Area }\end{array}$ & $\begin{array}{c}\text { \% } \\
\text { change }\end{array}$ & $\begin{array}{c}\text { Grid } \\
\text { Size }\end{array}$ & $\begin{array}{c}\text { Avg. } \\
\text { WSE }\end{array}$ & $\begin{array}{c}\text { Inundation } \\
\text { Area }\end{array}$ & $\begin{array}{c}\text { \% } \\
\text { change }\end{array}$ & $\begin{array}{c}\text { Grid } \\
\text { Size }\end{array}$ & $\begin{array}{c}\text { Avg. } \\
\text { WSE }\end{array}$ & $\begin{array}{c}\text { Inundation } \\
\text { Area }\end{array}$ & $\begin{array}{c}\text { \% } \\
\text { change }\end{array}$ \\
\hline$(\mathrm{m})$ & $(\mathrm{m})$ & $\left(\mathrm{km}^{2}\right)$ & & $(\mathrm{m})$ & $(\mathrm{m})$ & $\left(\mathrm{km}^{2}\right)$ & & $(\mathrm{m})$ & $(\mathrm{m})$ & $\left(\mathrm{km}^{2}\right)$ & \\
\hline & & & & 3 & 210.90 & 2.94 & 0.00 & 3 & 221.28 & 3.16 & 0.00 \\
6 & 164.28 & 0.36 & 0.00 & 6 & 210.91 & 2.94 & 0.17 & 6 & 221.32 & 3.20 & 1.34 \\
9 & 164.34 & 0.37 & 2.42 & 9 & 210.94 & 2.96 & 0.68 & 9 & 221.33 & 3.21 & 1.61 \\
12 & 164.40 & 0.39 & 7.00 & 12 & 210.98 & 2.98 & 1.31 & 12 & 221.47 & 3.30 & 4.50 \\
15 & 164.54 & 0.39 & 8.19 & 15 & 210.99 & 3.00 & 2.05 & 15 & 221.41 & 3.26 & 3.39 \\
18 & 164.60 & 0.40 & 10.85 & 18 & 210.84 & 2.88 & -1.95 & 18 & 221.43 & 3.30 & 4.48 \\
21 & 164.74 & 0.42 & 15.76 & 21 & 211.06 & 3.01 & 2.55 & 21 & 221.46 & 3.33 & 5.55 \\
24 & 164.82 & 0.42 & 15.97 & 24 & 211.07 & 3.05 & 3.88 & 24 & 221.51 & 3.39 & 7.46 \\
27 & 164.94 & 0.45 & 23.00 & 27 & 211.05 & 3.05 & 3.73 & 27 & 221.56 & 3.39 & 7.48 \\
30 & 165.07 & 0.44 & 21.33 & 30 & 211.06 & 3.03 & 3.20 & 30 & 221.54 & 3.40 & 7.65 \\
33 & 165.19 & 0.48 & 32.35 & 33 & 211.17 & 3.10 & 5.56 & 33 & 221.59 & 3.49 & 10.56 \\
36 & 165.35 & 0.49 & 35.45 & 36 & 211.34 & 3.24 & 10.39 & 36 & 221.57 & 3.38 & 7.23 \\
48 & 165.79 & 0.52 & 43.84 & 48 & 211.31 & 3.24 & 10.40 & 48 & 221.76 & 3.64 & 15.35 \\
60 & 166.31 & 0.60 & 66.36 & 60 & 211.40 & 3.34 & 13.82 & 60 & 221.89 & 3.70 & 17.18 \\
70 & 166.67 & 0.61 & 68.86 & 70 & 211.65 & 3.56 & 21.28 & 70 & 221.97 & 3.81 & 20.59 \\
80 & 166.75 & 0.69 & 89.22 & 80 & 211.75 & 3.79 & 29.20 & 80 & 222.21 & 3.95 & 25.16 \\
90 & 167.29 & 0.70 & 93.52 & 90 & 212.04 & 4.26 & 45.08 & 90 & 221.93 & 3.74 & 18.47 \\
100 & 167.24 & 0.63 & 74.79 & 100 & 212.03 & 4.19 & 42.63 & 100 & 222.02 & 3.85 & 22.04 \\
\hline
\end{tabular}


Table 3. Effect of DEM resolution on hydraulic outputs for large reaches with agricultural land use

\begin{tabular}{|cccc|cccc|}
\hline \multicolumn{5}{|c|}{ Brazos River } & \multicolumn{4}{c|}{ East Fork White River } \\
\hline Grid Size & Avg. WSE & Inundation Area & \% change & Grid Size & Avg. WSE & Inundation Area & \% change \\
\hline$(\mathrm{m})$ & $(\mathrm{m})$ & $\left(\mathrm{km}^{2}\right)$ & & $(\mathrm{m})$ & $(\mathrm{m})$ & $\left(\mathrm{km}^{2}\right)$ & \\
\hline 3 & 22.73 & 162.29 & 0.00 & 3 & 155.06 & 18.39 & 0.00 \\
6 & 22.73 & 162.30 & 0.01 & 6 & 155.08 & 18.42 & 0.14 \\
9 & 22.75 & 164.35 & 1.27 & 9 & 155.08 & 18.42 & 0.14 \\
12 & 22.75 & 164.44 & 1.32 & 12 & 155.11 & 18.43 & 0.22 \\
15 & 22.77 & 166.16 & 2.38 & 15 & 155.11 & 18.43 & 0.19 \\
18 & 22.78 & 166.94 & 2.87 & 18 & 155.12 & 18.48 & 0.44 \\
21 & 22.79 & 169.25 & 4.29 & 21 & 155.13 & 18.46 & 0.36 \\
24 & 22.81 & 169.30 & 4.32 & 24 & 155.16 & 18.49 & 0.52 \\
27 & 22.82 & 170.63 & 5.14 & 27 & 155.18 & 18.48 & 0.47 \\
30 & 22.83 & 172.39 & 6.22 & 30 & 155.20 & 18.54 & 0.82 \\
33 & 22.84 & 174.11 & 7.28 & 33 & 155.22 & 18.57 & 0.94 \\
36 & 22.90 & 177.92 & 9.63 & 36 & 155.24 & 18.55 & 0.83 \\
48 & 22.92 & 177.58 & 9.42 & 48 & 155.35 & 18.65 & 1.40 \\
60 & 22.98 & 181.82 & 12.03 & 60 & 155.44 & 18.80 & 2.24 \\
70 & 23.02 & 184.67 & 13.79 & 70 & 155.58 & 18.99 & 3.24 \\
80 & 23.12 & 188.51 & 16.15 & 80 & 155.65 & 18.77 & 2.03 \\
90 & 23.07 & 190.10 & 17.14 & 90 & 155.82 & 18.93 & 2.94 \\
100 & 23.20 & 191.92 & 18.26 & 100 & 155.84 & 18.98 & 3.18 \\
\hline
\end{tabular}


Table 4. Validation results for Clear Creek

\begin{tabular}{|ccccccc|}
\hline Clear Creek & \multicolumn{7}{c|}{ WSE (m) for different cross-section station (m) } \\
\hline Grid Size (m) & $\mathbf{3 5 7 3 8 . 2}$ & $\mathbf{3 5 0 1 1 . 6}$ & $\mathbf{1 7 2 0 6 . 2}$ & $\mathbf{1 7 1 9 1 . 6}$ & $\mathbf{4 8 8 1 . 2}$ & $\mathbf{1 7 4 . 6}$ \\
\hline $\mathbf{3 0}$ & 228.72 & 228.95 & 215.44 & 215.59 & 203.16 & 198.05 \\
$\mathbf{4 8}$ & 229.23 & 229.67 & 215.53 & 216.06 & 204.05 & 198.90 \\
$\mathbf{6 0}$ & 229.21 & 229.69 & 216.01 & 216.44 & 204.32 & 198.89 \\
$\mathbf{7 0}$ & 229.49 & 229.66 & 216.53 & 216.87 & 204.92 & 199.21 \\
$\mathbf{8 0}$ & 229.30 & 229.71 & 216.68 & 217.16 & 205.22 & 198.85 \\
Slope & 0.012 & 0.014 & 0.028 & 0.032 & 0.041 & 0.017 \\
Intercept & 228.47 & 228.75 & 214.45 & 214.58 & 201.97 & 197.79 \\
$\mathbf{R}^{\mathbf{2}}$ & 0.72 & 0.66 & 0.91 & 0.99 & 0.99 & 0.60 \\
LiDAR (base) & 228.30 & 228.68 & 214.74 & 214.91 & 203.16 & 198.75 \\
Predicted (new) & 228.49 & 228.76 & 214.48 & 214.61 & 202.01 & 197.80 \\
\hline
\end{tabular}


Table 5. RMSE of WSE between extrapolated values by using coarser resolution DEM and those obtained by using the LiDAR

\begin{tabular}{|cccc|}
\hline Study Area & $\begin{array}{c}\text { Reach Length } \\
(\mathrm{km})\end{array}$ & $\begin{array}{c}\text { RMSE } \\
(\mathrm{m})\end{array}$ & Avg. Slope \\
\hline Brazos River & 59.9 & 0.08 & 0.00009 \\
Clear Creek & 39.0 & 0.66 & 0.00079 \\
East Fork White River & 20.2 & 0.10 & 0.00001 \\
St. Joseph River & 11.1 & 0.55 & 0.00018 \\
Tippecanoe River & 10.4 & 0.26 & 0.00025 \\
Strouds Creek & 6.5 & 0.75 & 0.00562 \\
\hline
\end{tabular}


Figures

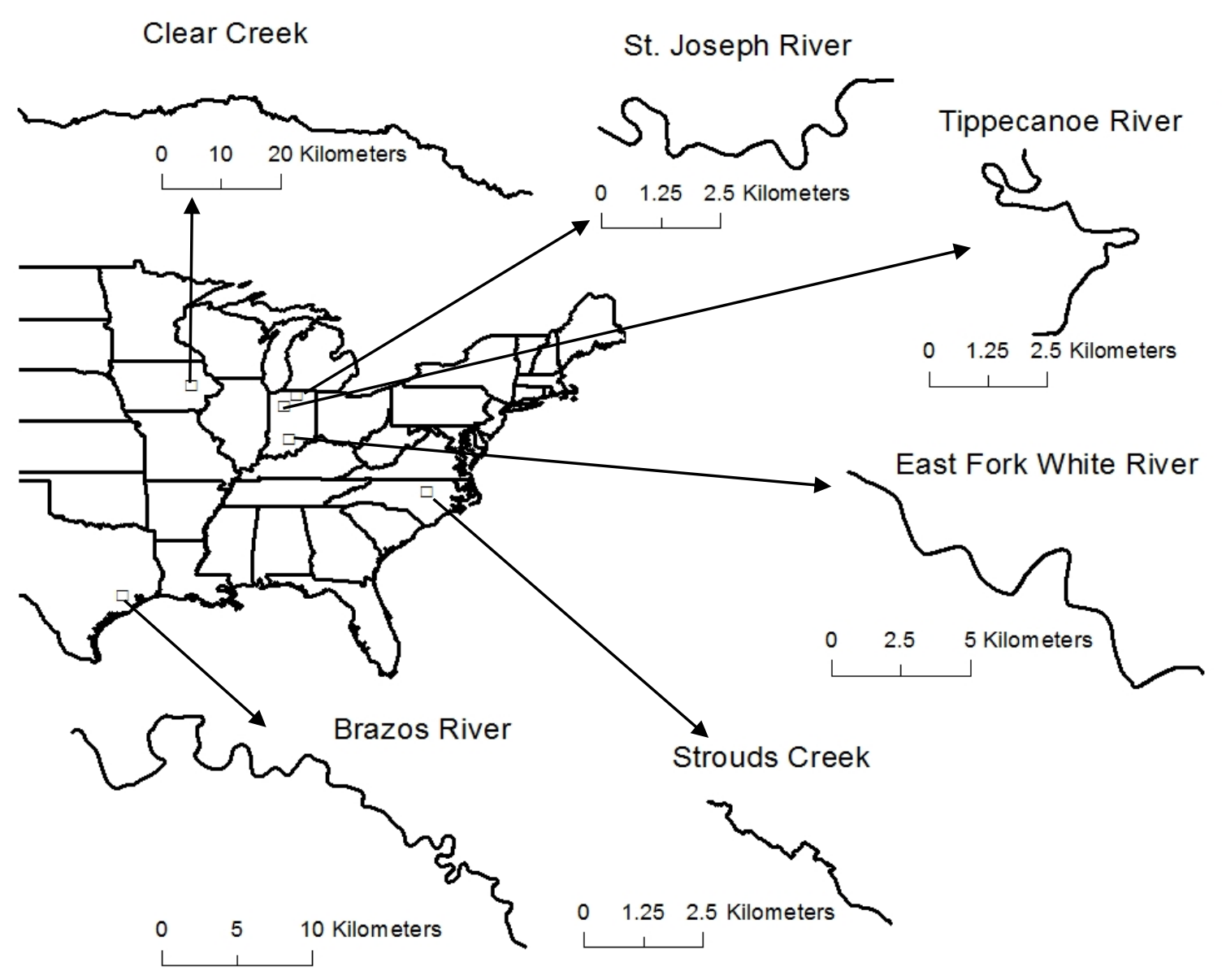

Figure 1. Layout map of study areas 

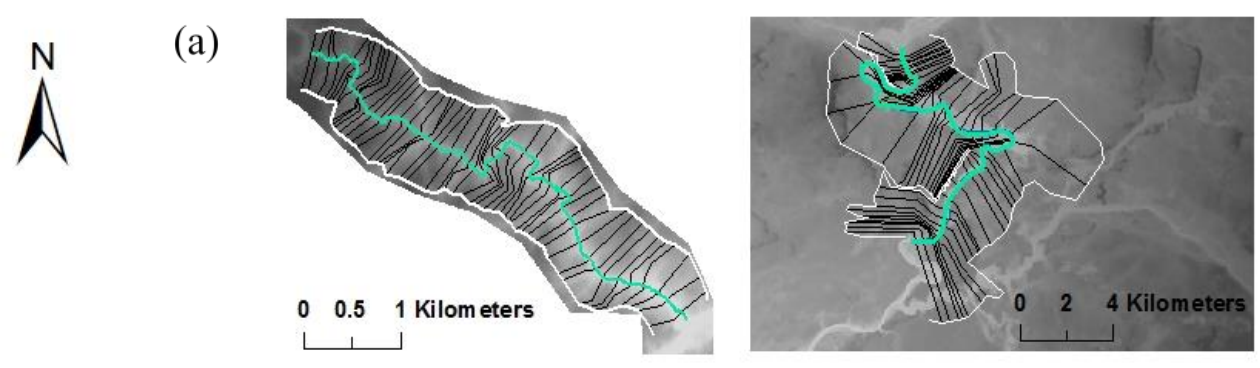

(b)

(c)
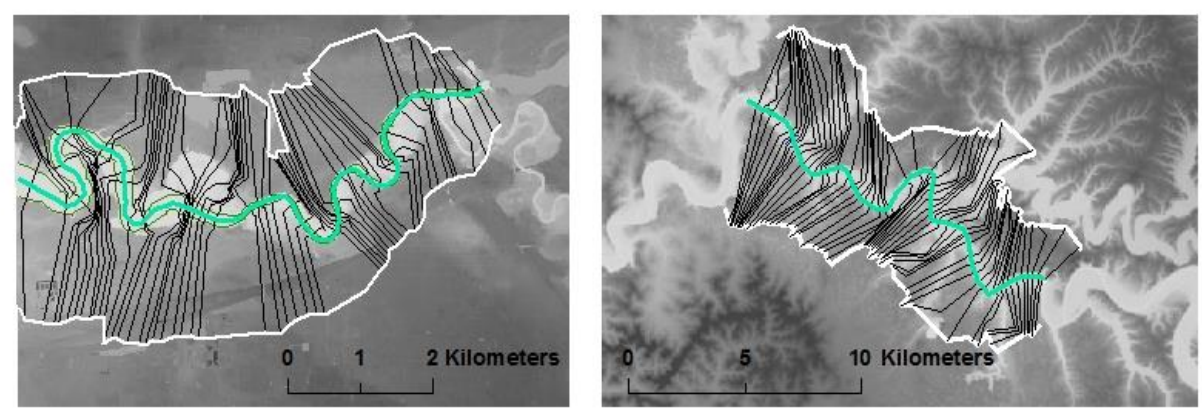

(d)

(e)
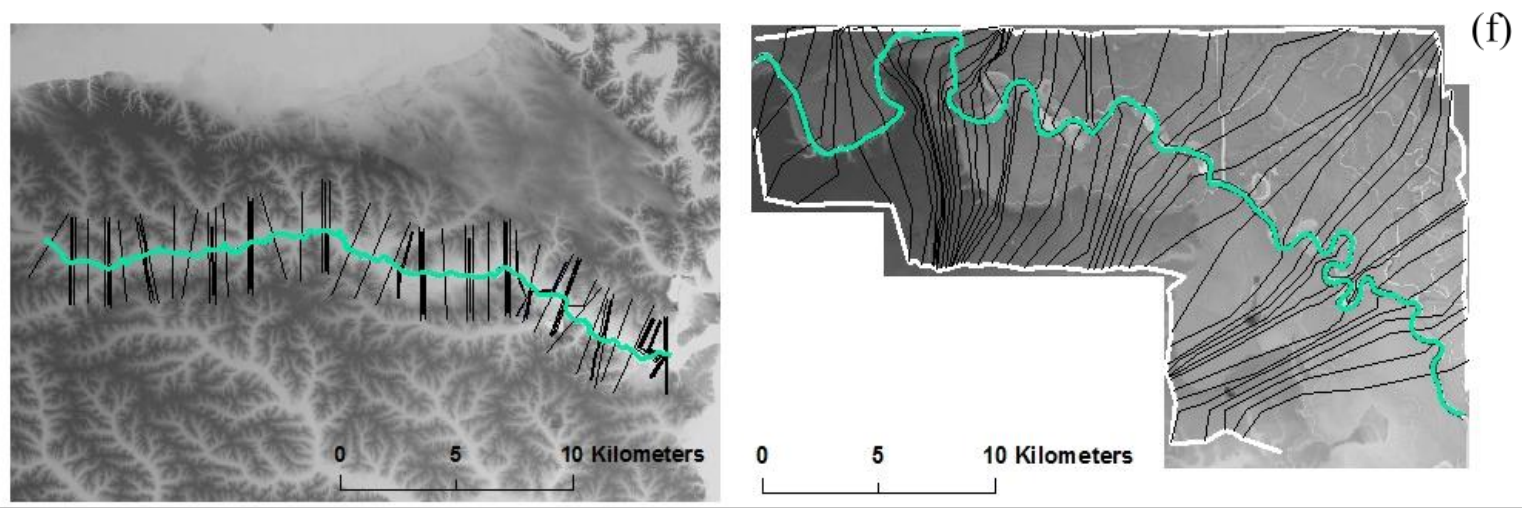

Figure 2. LiDAR DEMs with cross-sectional configuration, (a) Strouds Creek; (b) Tippecanoe River; (c) St. Joseph River; (d) East Fork White River; (e) Clear Creek; and (f) Brazos River 


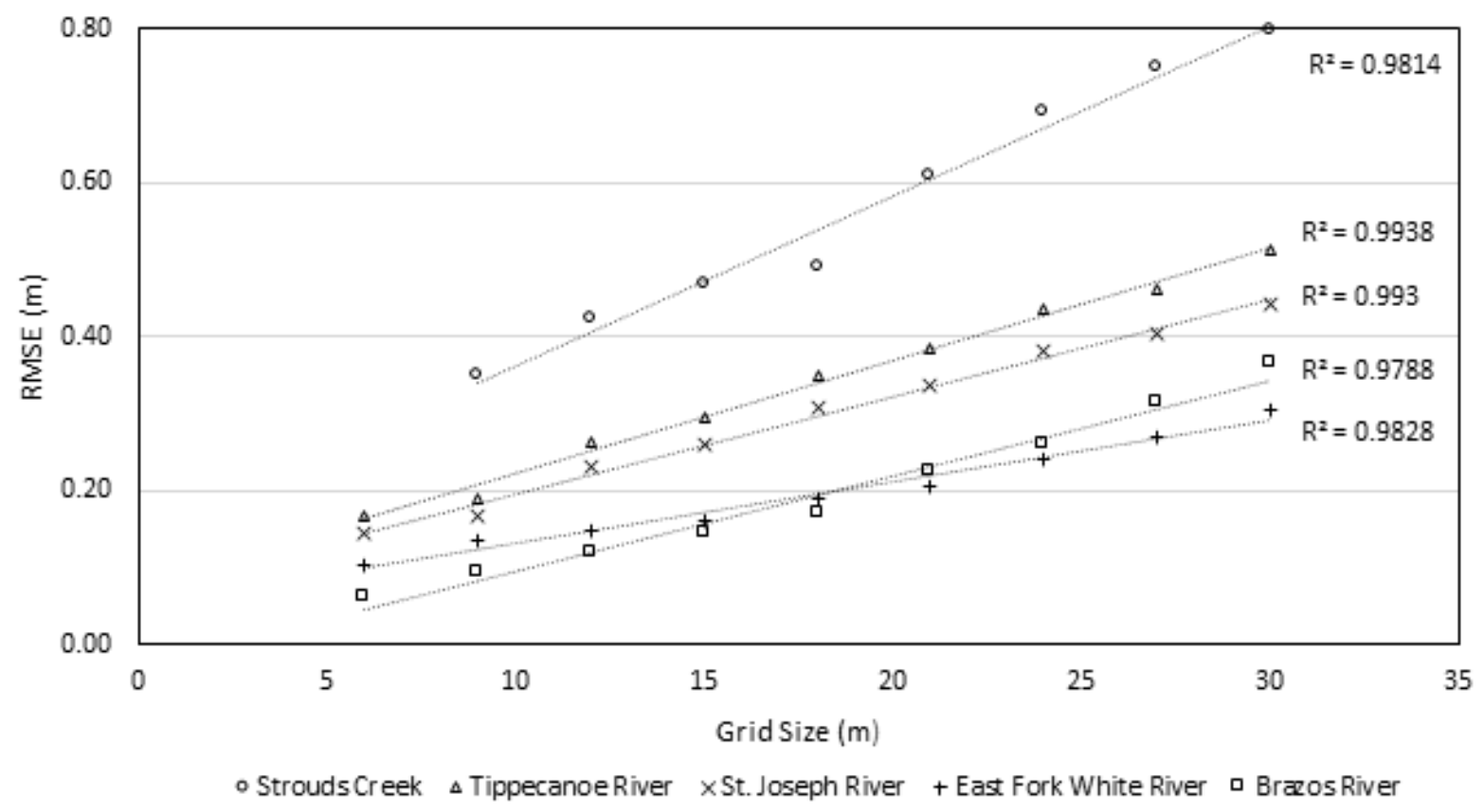

Figure 3. RMSE versus grid size for Strouds Creek, Tippecanoe River, St. Joseph River, East Fork White River and Brazos River 

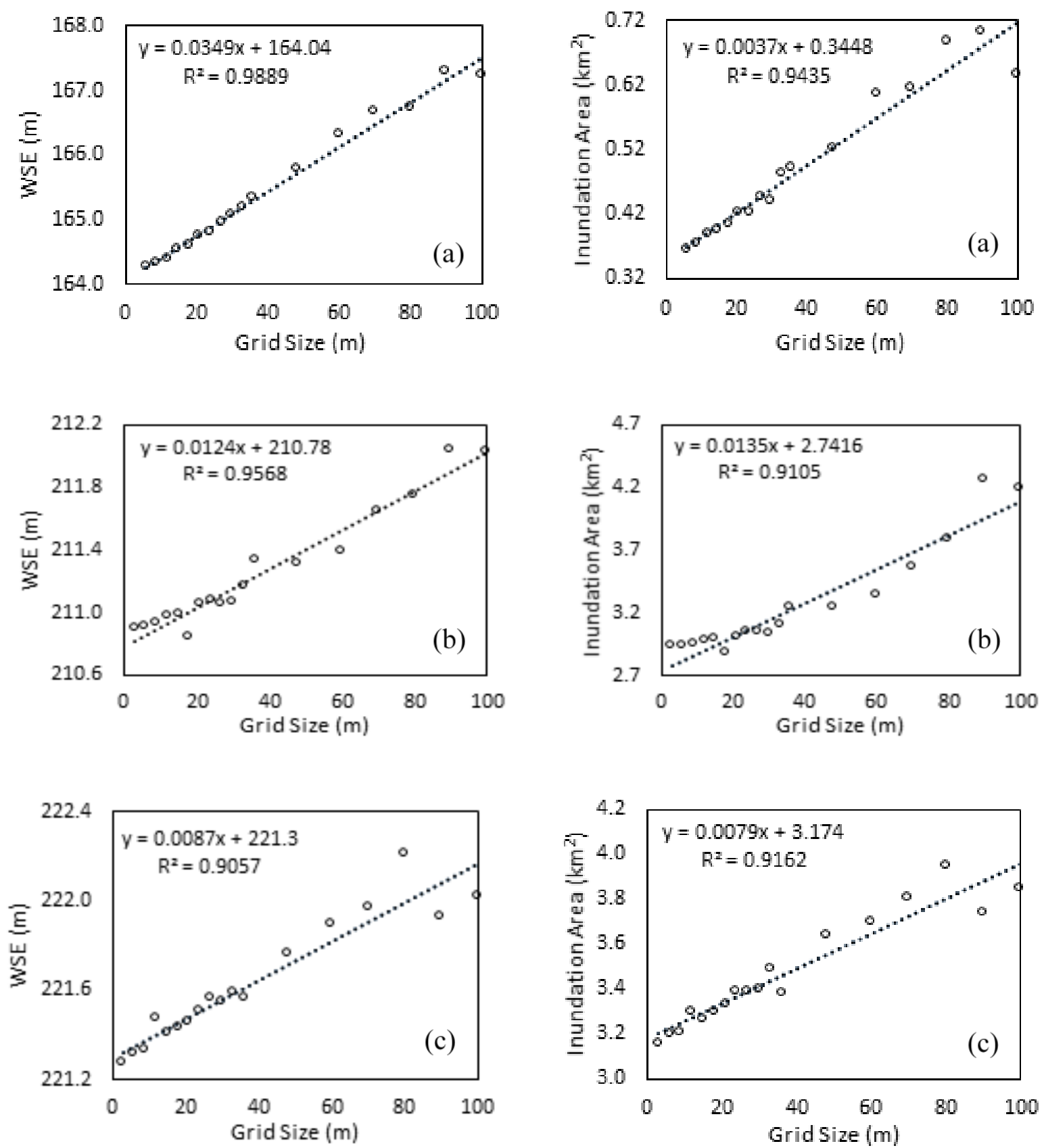

Figure 4. Average WSE and Inundation area versus grid size, (a) Strouds Creek; (b) Tippecanoe River; and (c) St. Joseph River 

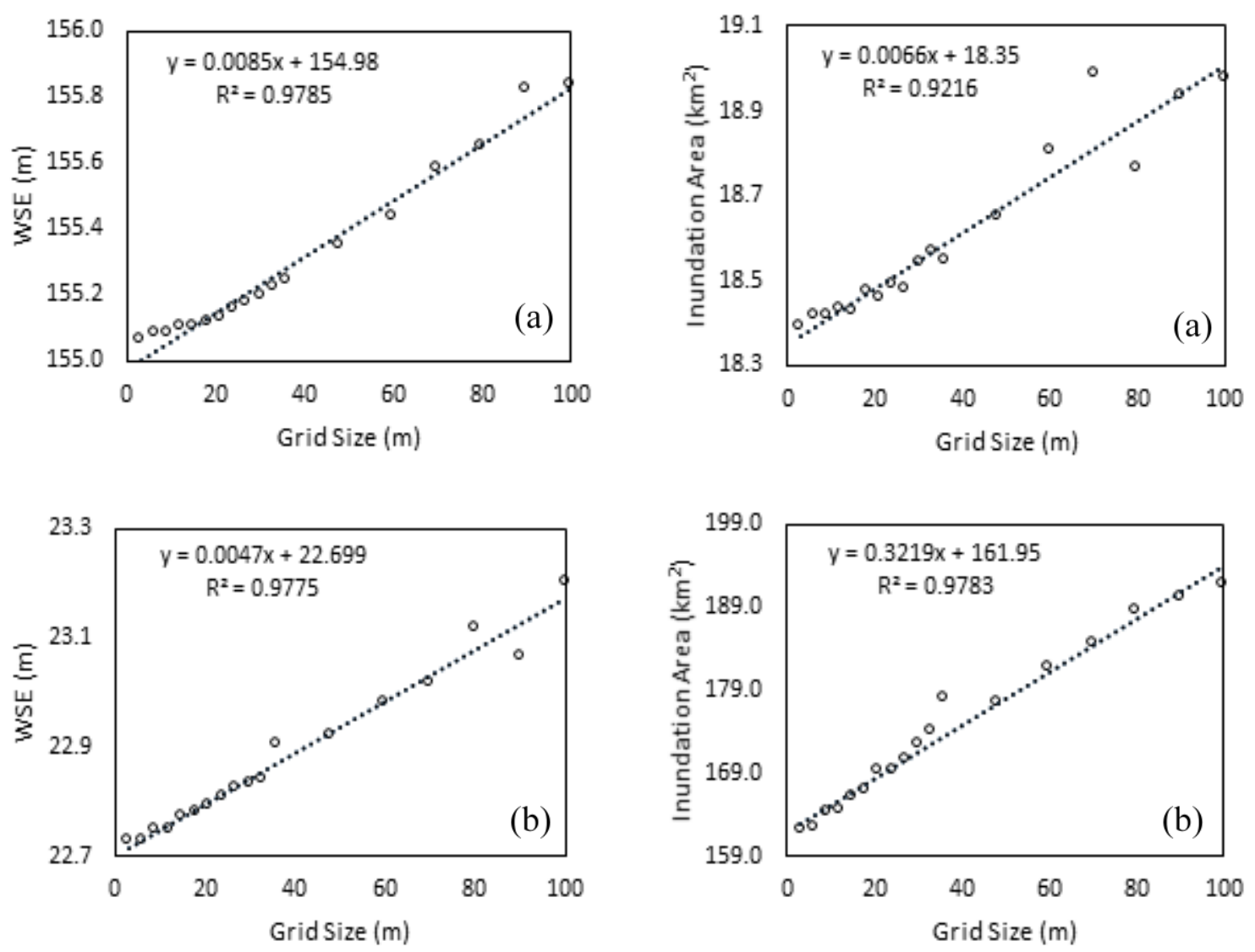

Figure 5. Average WSE and Inundation area versus grid size, (a) East Fork White River; and (b) Brazos River 

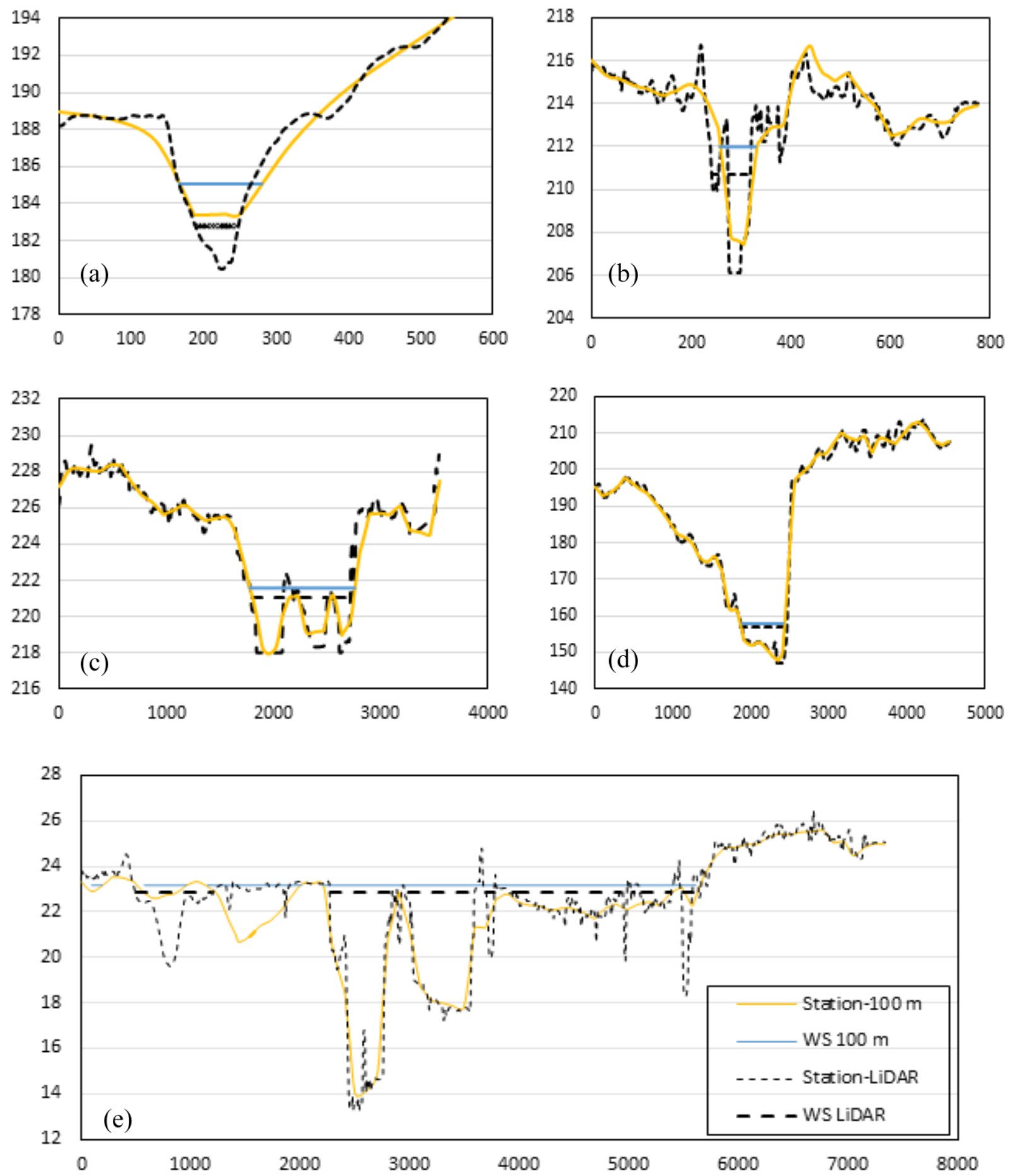

Figure 6. Cross-sectional profiles for LiDAR and $100 \mathrm{~m}$ DEMs with Elevation (m) on y-axis and Station (m) on X-axis, (a) Strouds Creek; (b) Tippecanoe River; (c) St. Joseph River; (d) East Fork White River; and (e) Brazos River 


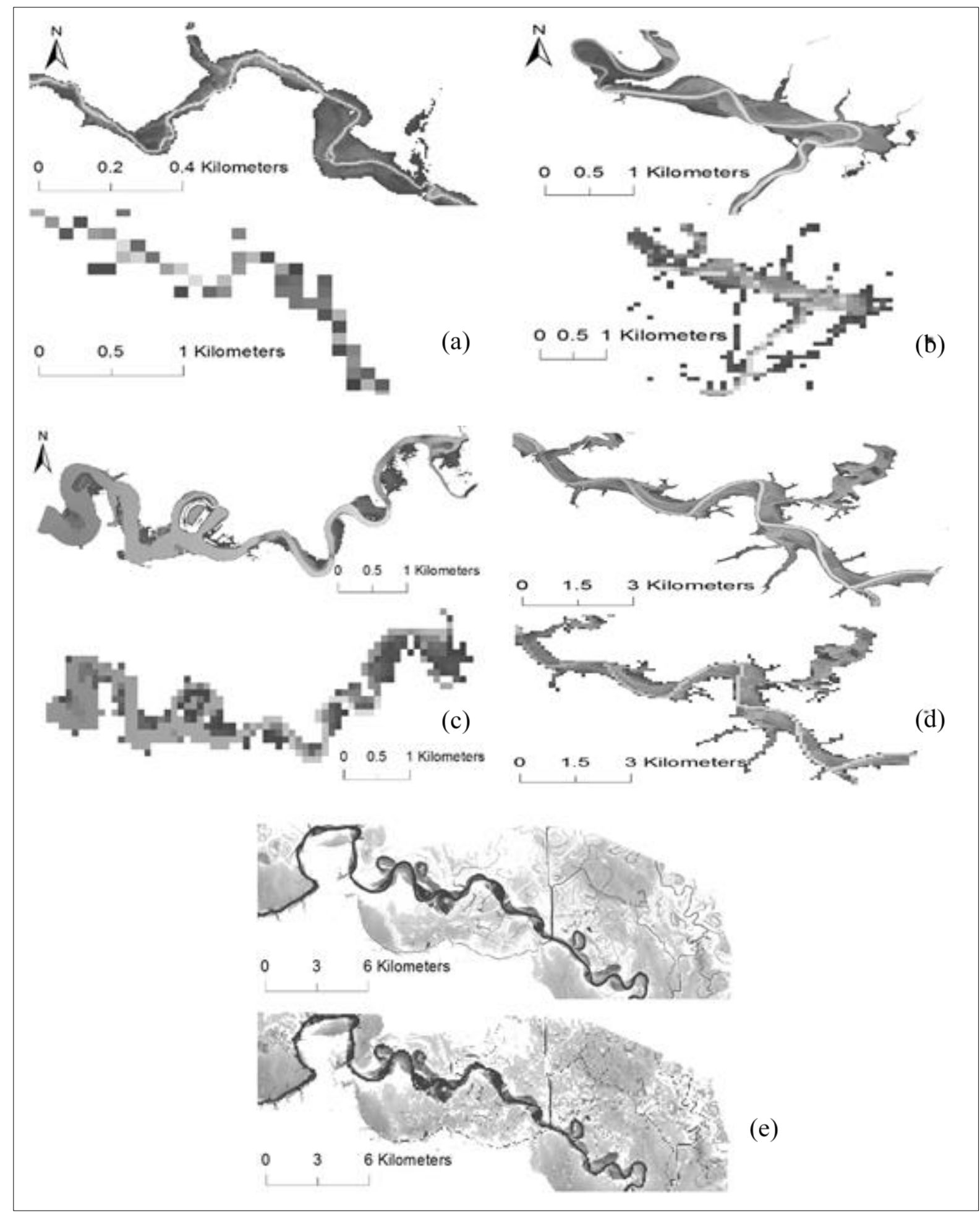

Figure 7. Comparison of LiDAR and 100 m flood maps, (a) Strouds Creek; (b) Tippecanoe River; (c) St. Joseph River; (d) East Fork White River; and (e) Brazos River 

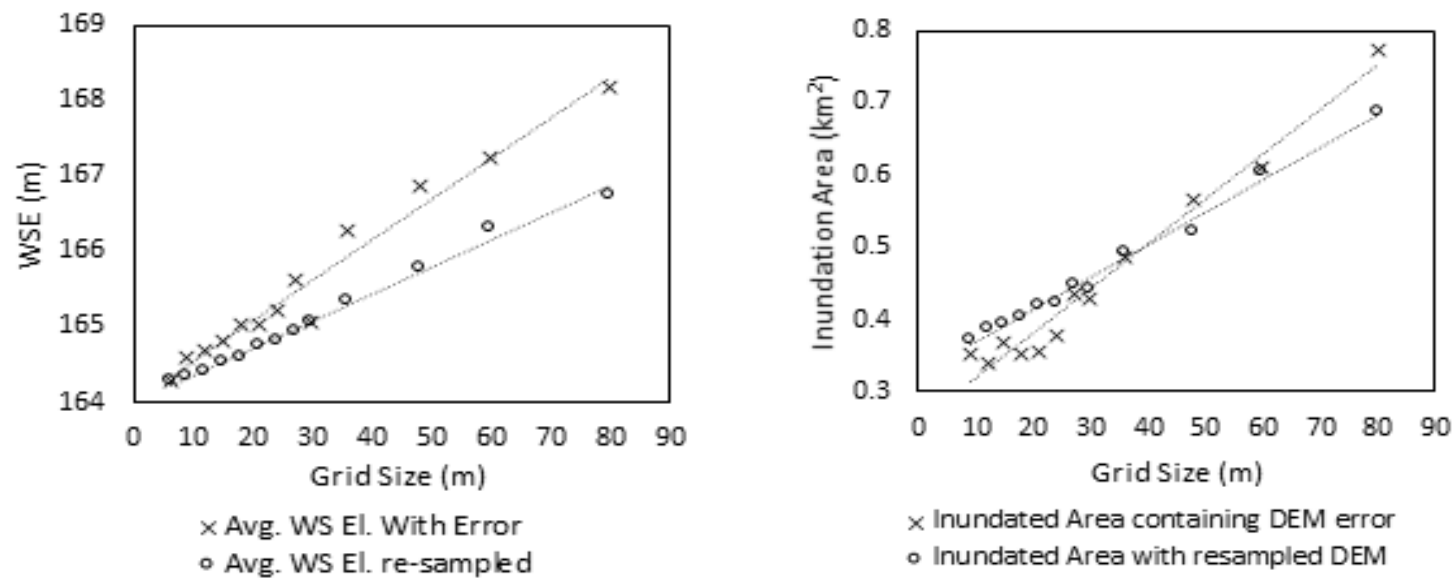

Figure 8. Hydraulic outputs versus grid size comparisons for DEMs containing errors and resampled DEMs (Strouds Creek) 


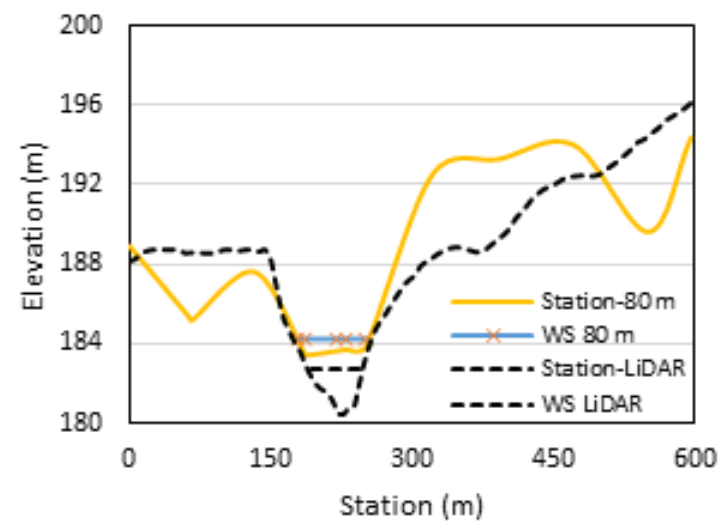

Figure 9. Cross-sectional profiles comparisons for LiDAR and $100 \mathrm{~m}$ DEM containing error (Strouds Creek) 


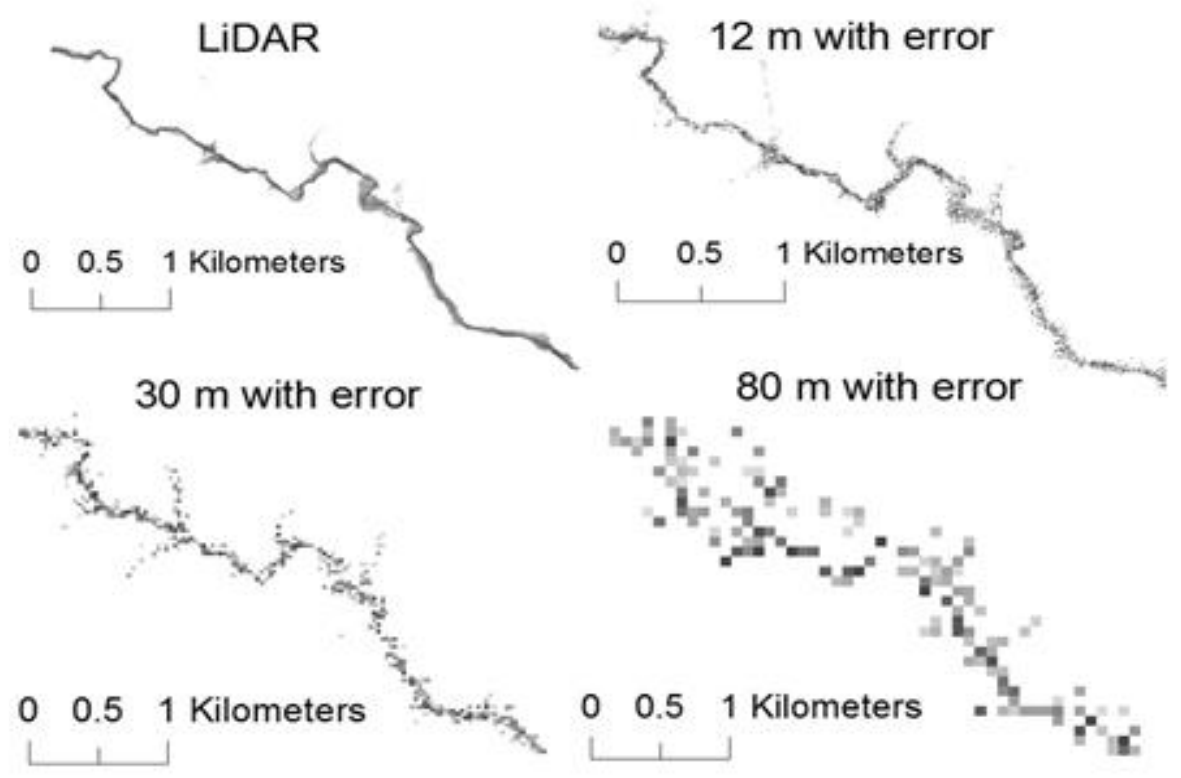

Figure 10. Comparison of flood maps between LiDAR and DEMs with errors (Strouds Creek) 

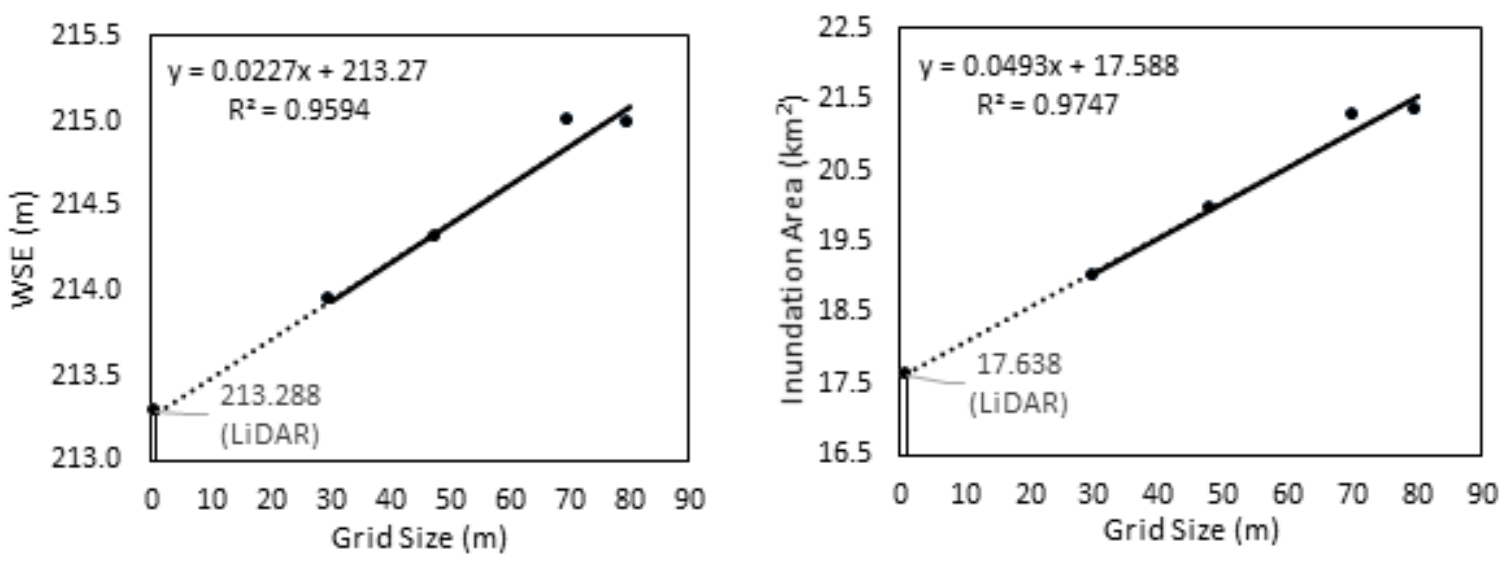

Figure 11. Extrapolation of linear regression results for validation (Clear Creek) 

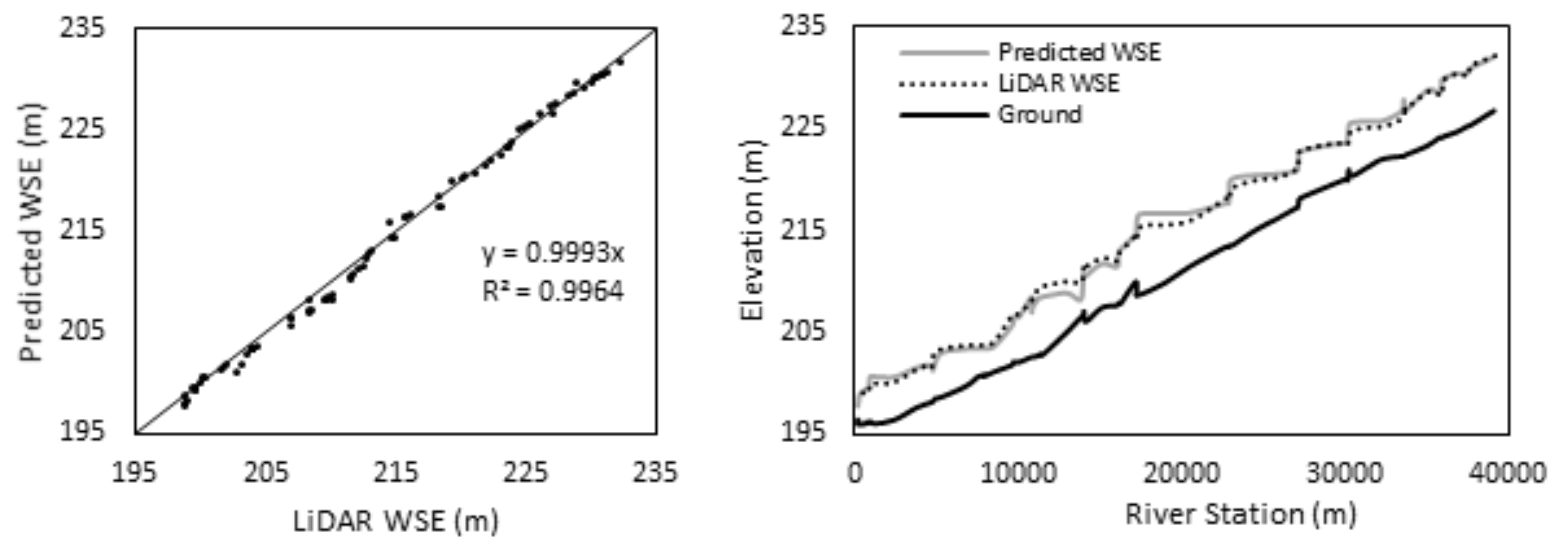

Figure 12. Predicted versus LiDAR WSE and water surface profile comparison (Clear Creek) 

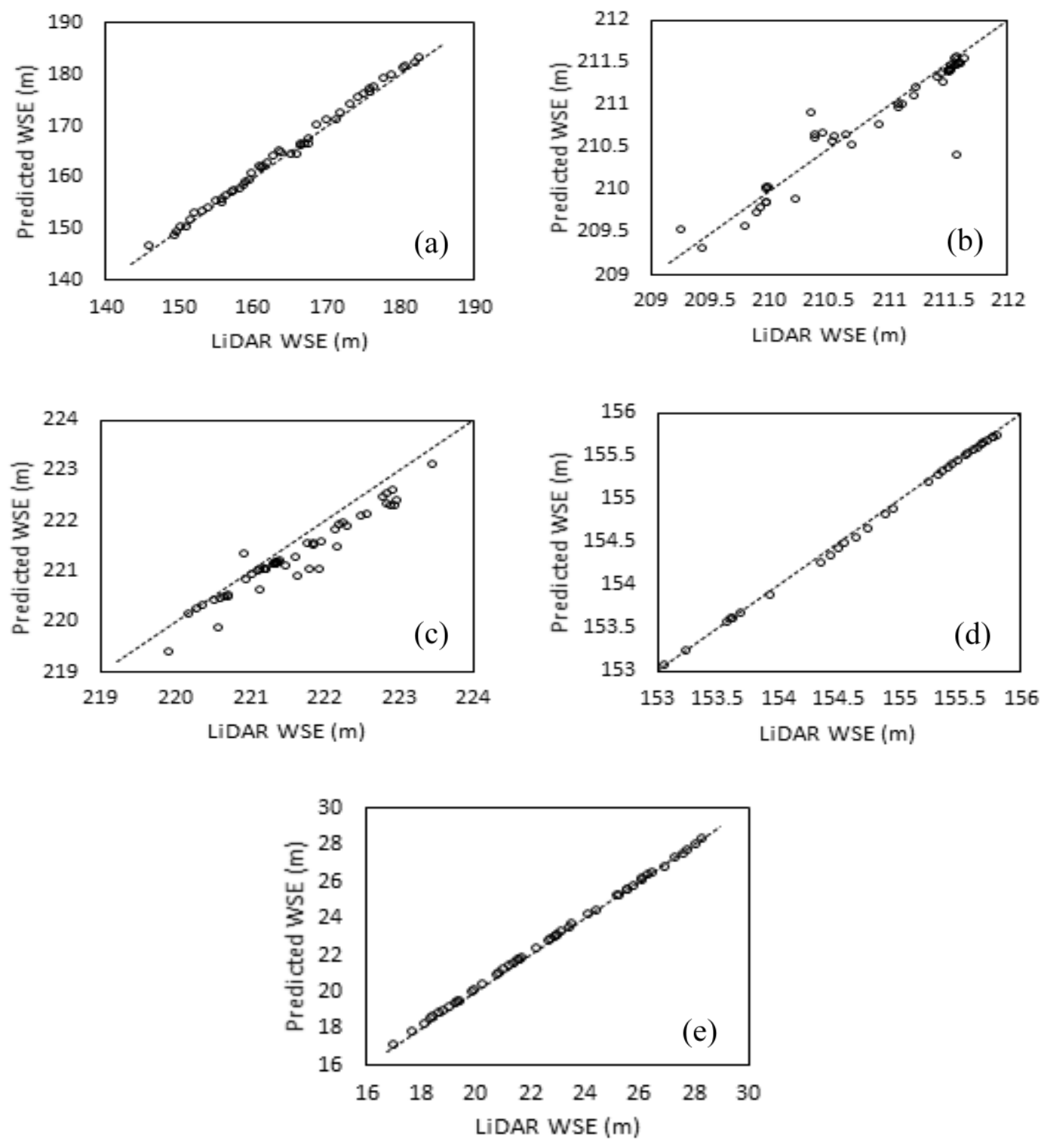

Figure 13. Predicted versus LiDAR WSE, (a) Strouds Creek; (b) Tippecanoe River; (c) St. Joseph River; (d) East Fork White River; and (e) Brazos River 

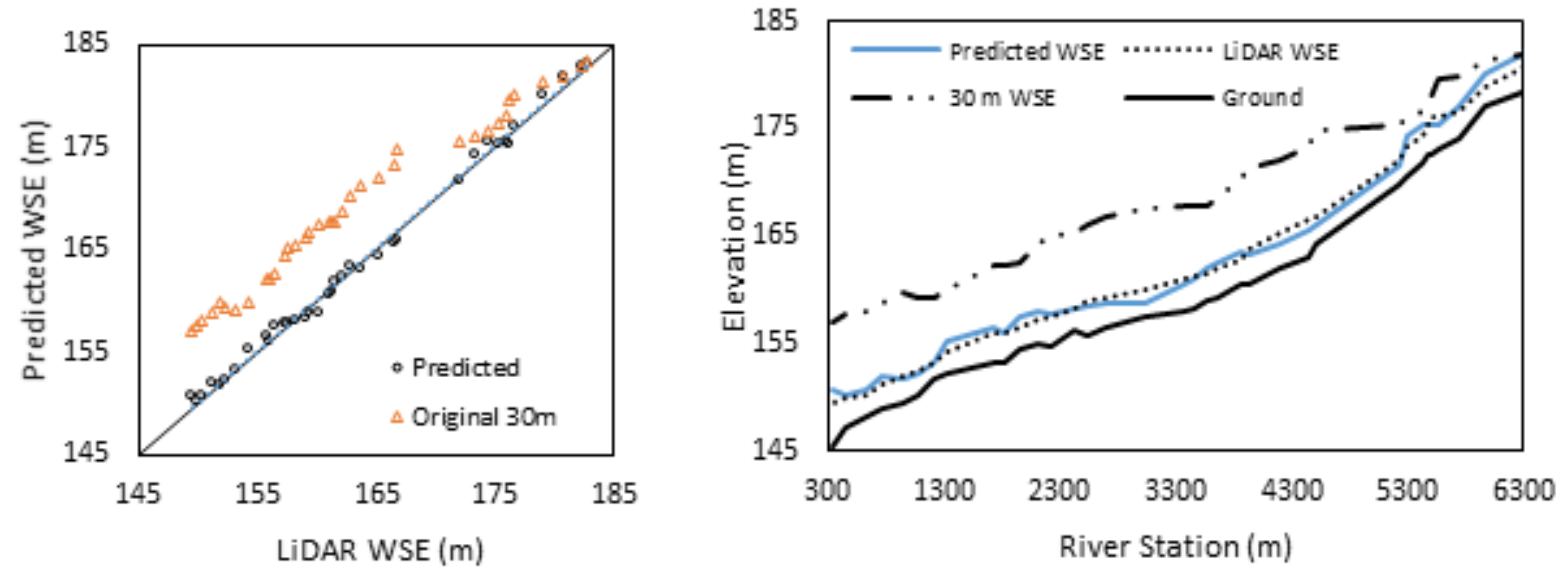

Figure 14. Comparison of WSE and water surface profile for $30 \mathrm{~m}$ DEM with error and predicted results with respect to LiDAR (Strouds Creek) 

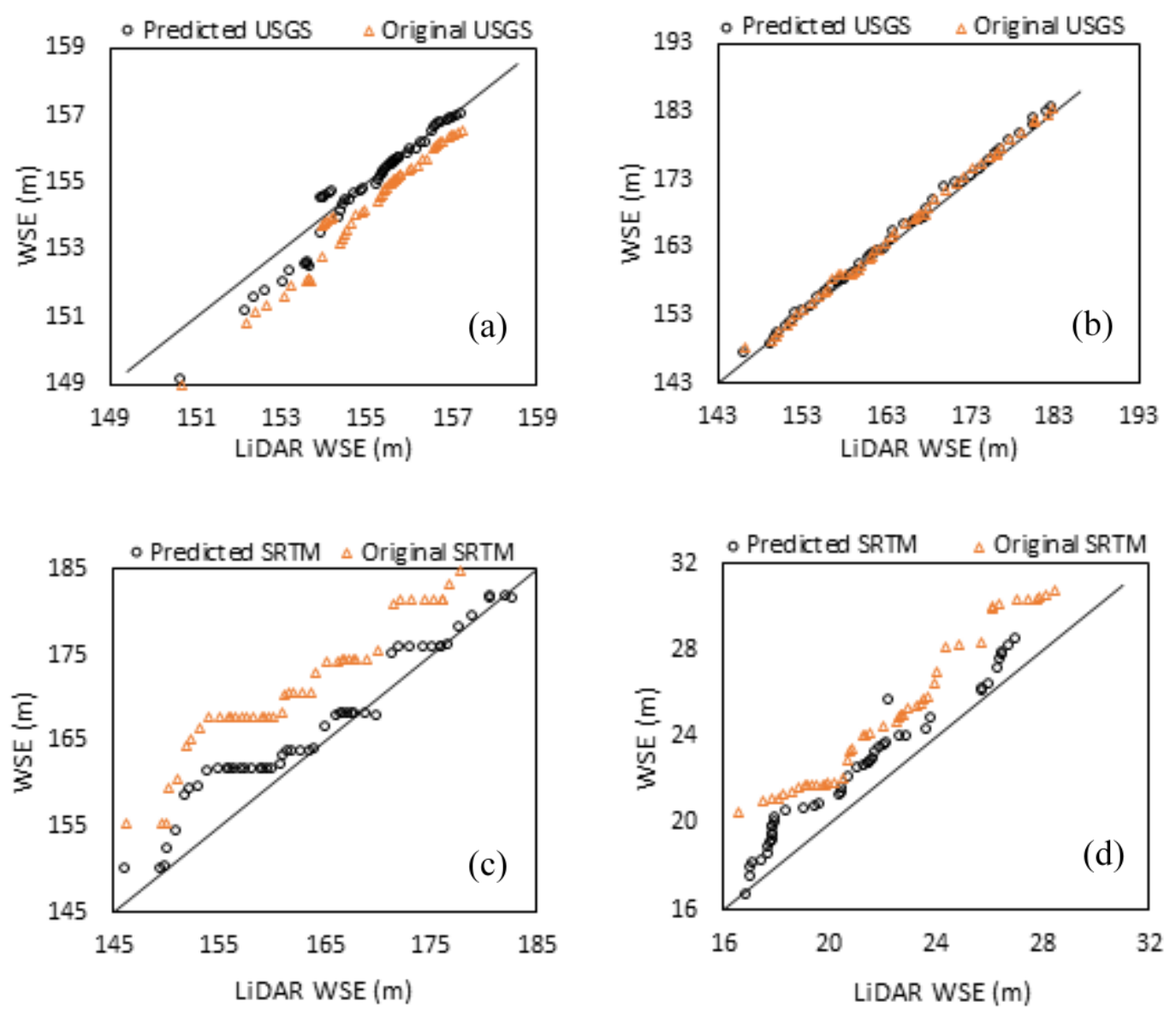

Figure 15. Predicted and original WSE versus LiDAR WSE, (a) Strouds Creek USGS; (b) East Fork White River USGS; (c) Strouds Creek SRTM; and (d) Brazos River SRTM 